INTER NATIONAL MONETARY FUND

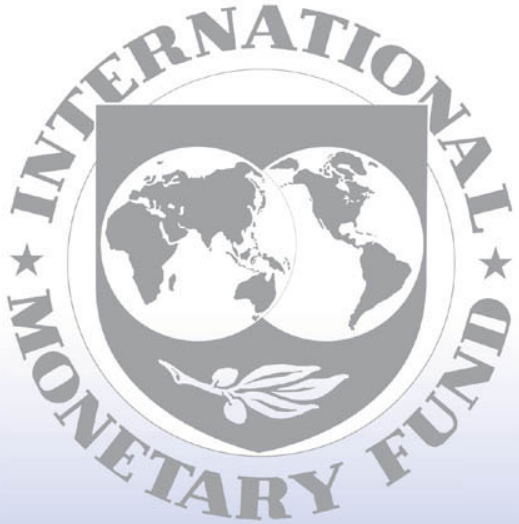

Staff

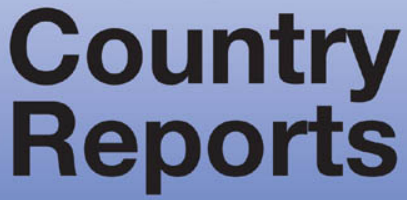




\title{
Spain: 2007 Article IV Consultation-Staff Report; Staff Statement; and Public Information Notice on the Executive Board Discussion
}

Under Article IV of the IMF's Articles of Agreement, the IMF holds bilateral discussions with members, usually every year. In the context of the 2007 Article IV consultation with Spain, the following documents have been released and are included in this package:

- the staff report for the 2007 Article IV consultation, prepared by a staff team of the IMF, following discussions that ended on March 26, 2007, with the officials of Spain on economic developments and policies. Based on information available at the time of these discussions, the staff report was completed on April 25, 2007. The views expressed in the staff report are those of the staff team and do not necessarily reflect the views of the Executive Board of the IMF;

- $\quad$ a staff statement of May 16, 2007 updating information on recent developments; and

- $\quad$ a Public Information Notice (PIN) summarizing the views of the Executive Board as expressed during its May 16, 2007 discussion of the staff report that concluded the Article IV consultation.

The policy of publication of staff reports and other documents allows for the deletion of market-sensitive information.

To assist the IMF in evaluating the publication policy, reader comments are invited and may be sent by e-mail to publicationpolicy@imf.org.

\author{
Copies of this report are available to the public from \\ International Monetary Fund • Publication Services \\ $70019^{\text {th }}$ Street, N.W. • Washington, D.C. 20431 \\ Telephone: (202) 623-7430 • Telefax: (202) 623-7201 \\ E-mail: publications@imf.org •Internet: http://www.imf.org
}

Price: $\$ 18.00$ a copy

\section{International Monetary Fund \\ Washington, D.C.}


This page intentionally left blank 


\section{INTERNATIONAL MONETARY FUND}

\section{SPAIN \\ Staff Report for the 2007 Article IV Consultation}

Prepared by the Staff Representatives for the 2007 Consultation with Spain

Approved by Michael Deppler and G. Russell Kincaid

April 24, 2007

\section{EXECUTIVE SUMMARY AND INTRODUCTION}

Background: The Spanish economy enjoyed another year of remarkable growth in 2006, further extending its prolonged expansion. Output growth gathered pace in the course of 2006 to reach 3.9 percent for the year; brisk job creation absorbed further increases in female participation and immigration; and inflation moderated appreciably. There were also signs of some rebalancing in the sources of growth, away from consumption and construction and toward corporate investment and exports. Specifically, higher interest rates and weaker household finances dampened private consumption, while strong corporate profitability sustained the pickup in nonhousing investment. At the same time, the revival in partner demand reduced the external sector's drag on growth, which however remained large. Revenue buoyancy lifted the general government balance to a record surplus (1.8 percent of GDP). Private sector indebtedness, however, reached new highs, and the current account deficit widened to 8.8 percent of GDP.

Outlook and risks: Immediate growth prospects are bright and the central scenario is for a smooth landing but with appreciable downside risks. The main risk is that agents may adjust their balance sheets more rapidly than anticipated, and that - given significant domestic market rigidities encumbering a quick shift of resources to export sectors - regaining competitiveness within EMU may entail a protracted period of weak activity.

Policy recommendations: Forestalling such an adverse scenario entails three policy priorities: safeguarding budgetary stability while tempering demand; raising supply capacity and improving competitiveness; and keeping the financial sector strong. Institutional mechanisms for fiscal discipline at all levels of government need to be strengthened. Competition-enhancing efforts should be stepped up and backed by political commitment. Worthwhile pending economic legislation should proceed forthwith. While agreeing on the nature of the underlying risks, the authorities assigned lesser probability to adverse scenarios, and thus less urgency to staff's recommendations, which they nonetheless generally shared. 


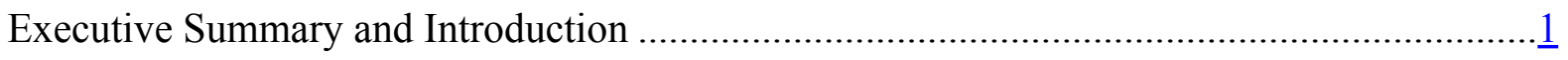

I. Outlook: A Bright Near Term but Clouds Further Out ......................................................

II. Fiscal Policy: Preserving Budgetary Stability While Tempering Demand........................ $\underline{9}$

III. Raising Supply Capacity and Improving Competitiveness ............................................11

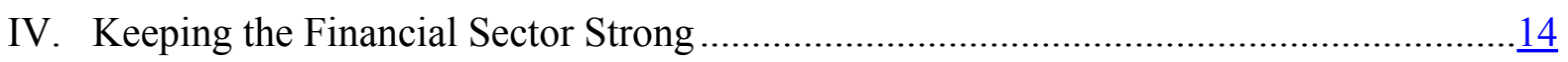

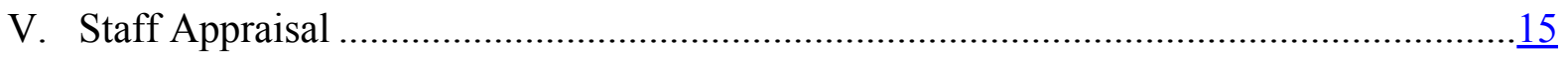

Tables

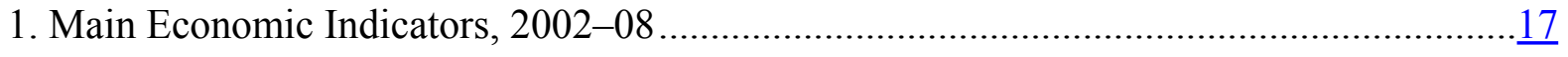

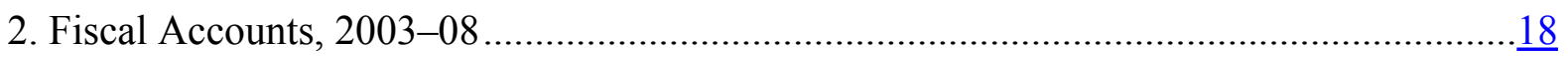

3. Indicators of External and Financial Vulnerability, 2002-06 .........................................19

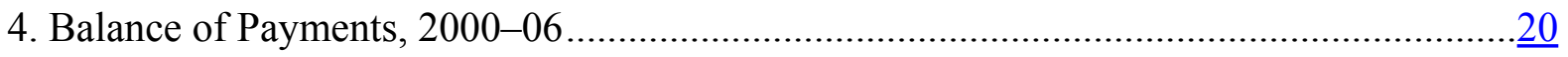

5. Medium-Term Projections of the Balance of Payments ....................................................

6. Status of Implementation of Main FSAP Recommendations ..............................................

Figures

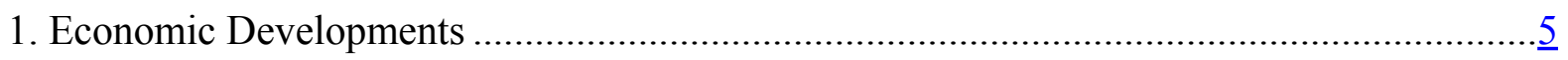

2. Deteriorating Competitiveness ................................................................................

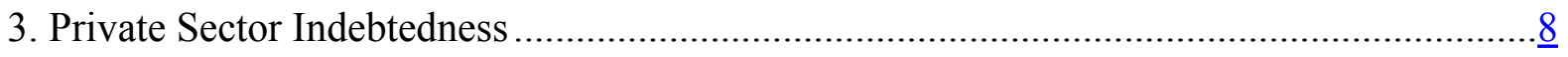

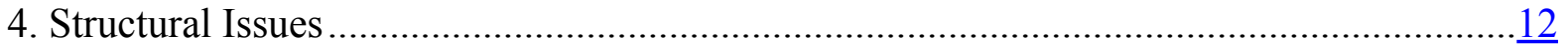

Box

1. Implementation of Fund Policy Recommendations...........................................................

Appendixes

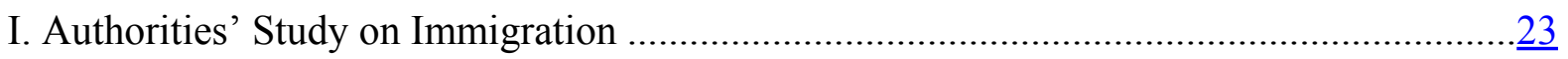

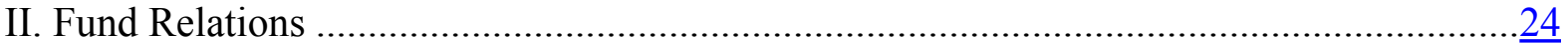




\section{Outlook: A Bright Near Term but Clouds Further OUT}

1. Following Spain's remarkably prolonged expansion, the authorities (and staff) project growth to decelerate gradually in 2007-08 toward its estimated potential, but the external deficit will remain large. Under both projections, the impetus from consumption is expected to moderate further - partly offset by firming net exports. Indeed, higher interest rates and indebtedness are already reining in consumption and cooling the housing market (Figure 1). The same forces are projected to curb the growth of investment over 2007-08, whose level will nevertheless remain high. Over the medium term, the rise in nonhousing investment and continued favorable external environment are projected to sustain the productivity gains underway in manufacturing. In sum, both staff and official projections envisage that domestic spending will decelerate gradually, avoiding a pronounced slowdown but keeping the current account deficit high - in staff's projections at around $91 / 2-10$ percent of GDP through the forecast horizon.

\section{The main risk to this expansion} remains high private sector indebtedness and the related large current account deficit. Given Spain's membership in EMU and the strength of its financial sector, availability of external financing is not a constraint. Nevertheless, the external deficit is symptomatic of the risks to medium-term growth. First, it reflects weak competitiveness stemming from poor productivity performance and resilient price and labor cost
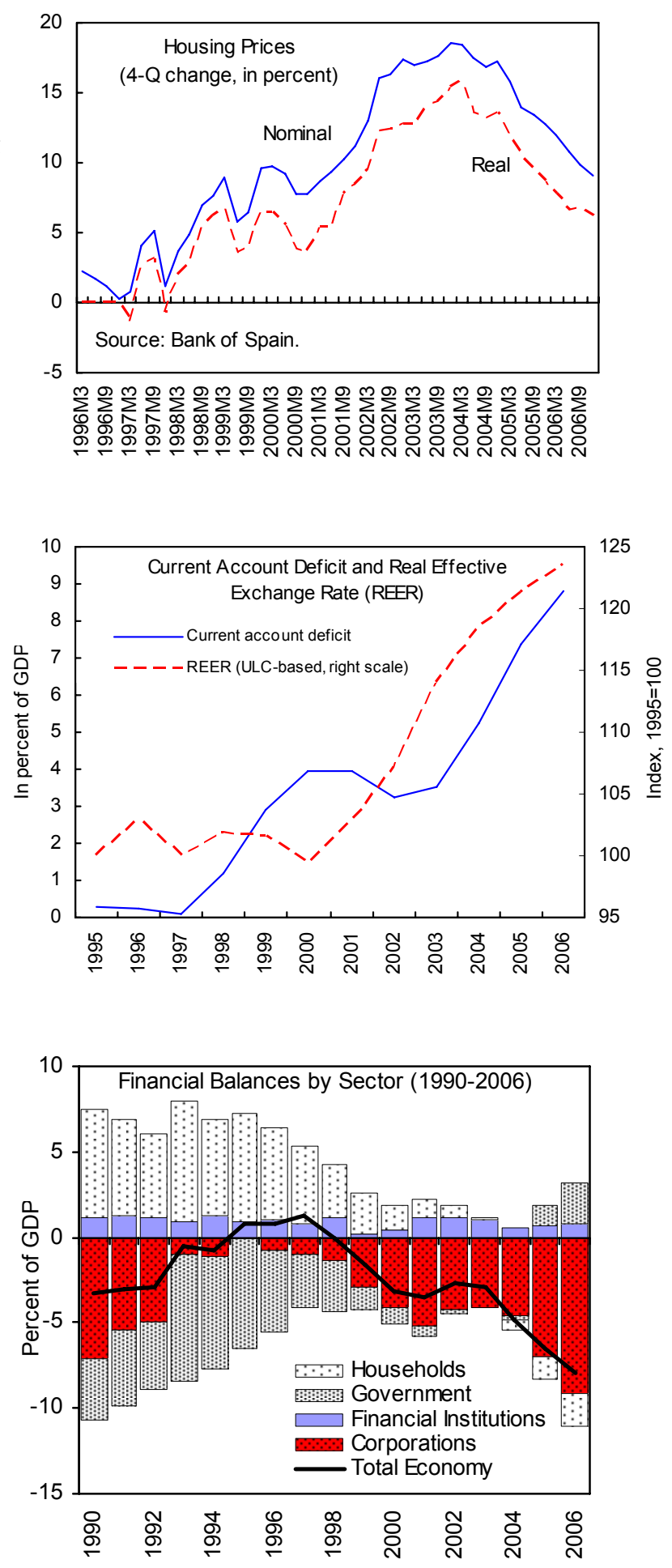

Source: Bank of Spain. Note: 2006 includes data through Q3 only and is a sum of most recent 12 months. 
differentials with trading partners (Figure 2). ${ }^{1}$ While there are signs of a manufacturing productivity revival, it has yet to prove its persistence beyond the cyclical upturn. Second, sustained borrowing has raised nonfinancial private sector indebtedness to 187 percent of GDP (mainly at variable rates for households), among the highest in the OECD (Figure 3). Staff illustrated the medium-term implications of the projected external deficits for the country's private sector indebtedness (text chart) and net external liability position (an increase of about 30 percentage points of GDP over the next

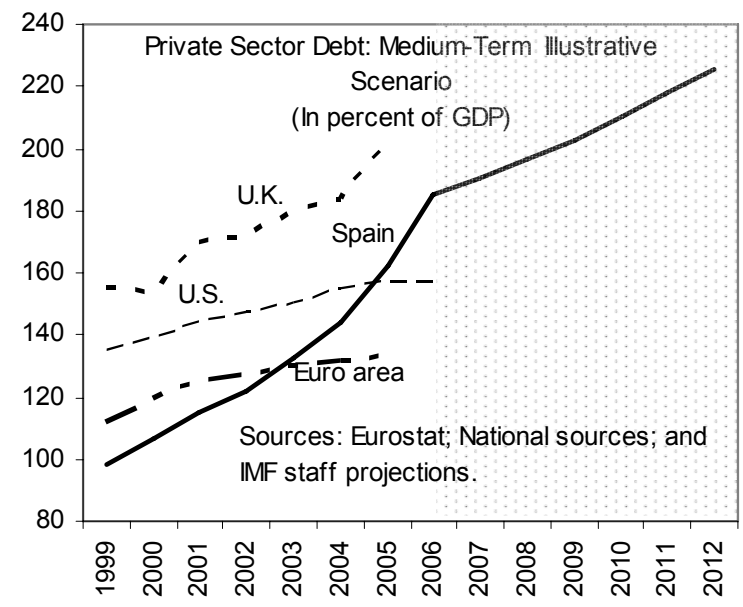
five years from the current 58 percent of GDP_-Table 5). In its view, these projections point to significant risks of pronounced balance-sheet retrenchment as low- and middle-income households might be unable or unwilling to continue to accumulate debt. A possible pronounced correction of real estate valuations, spilling over to construction investment (which accounts for one percentage point of GDP growth and 14 percent of employment) would compound such a retrenchment.

\section{Though agreeing on the nature of the underlying risks, the authorities assigned a}

lesser probability to the risk scenario. While there was no denying that the accumulation of private sector liabilities has an intrinsic limit, determining such a limit within EMU was considered a very uncertain exercise, venturing into "uncharted territory." Various factors were viewed as working toward a smooth reabsorption of the accumulated imbalances. First, the incipient rebalancing of growth enhanced prospects for a soft landing, and the current combination of rising interest rates and strong demand abroad was seen as optimal for Spain. Second, the recent manufacturing productivity gains, inflation declines, and export pick-up augured well for the environment going forward. Third, Spain had undergone profound structural changes in the recent past (among which a 5 million increase in population), with a strongly positive impact on its supply capacity (Appendix I). Fourth, the overall solvency position of the household sector was viewed as healthy given the comparatively large size of nonfinancial (housing) wealth. Finally, the fact that the process reflected private sector saving and investment decisions was also viewed as reassuring.

\footnotetext{
${ }^{1}$ Staff's assessment of Spain's REER gap (some 20-28 percent), has not materially changed from IMF Country Report No. 06/211. The statistical and methodological uncertainties of such estimates, and the authorities' related strong reservations, noted in that Report, also still hold. Illustratively, annual nominal wage increases would have to be below $1 \frac{1}{4}$ percent to achieve a 20 percent REER depreciation over 10 years with annual manufacturing productivity growth of $1 \frac{1}{2}$ percent-underscoring the importance of raising productivity.
} 
Figure 1. Spain: Economic Developments

Spain's convergence continued in $2006 .$.

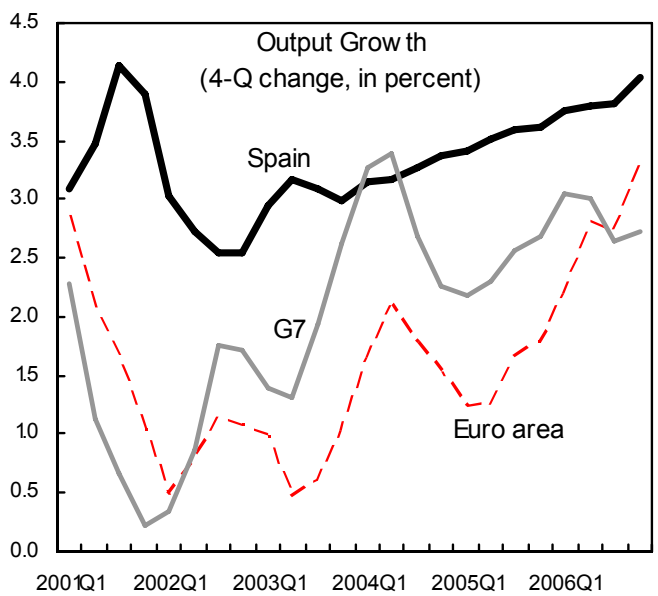

The recovery of industrial production...

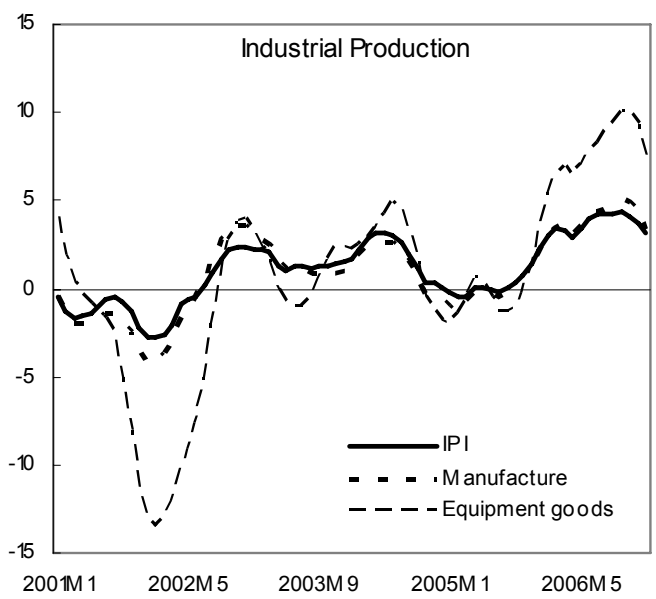

Job creation remains strong.

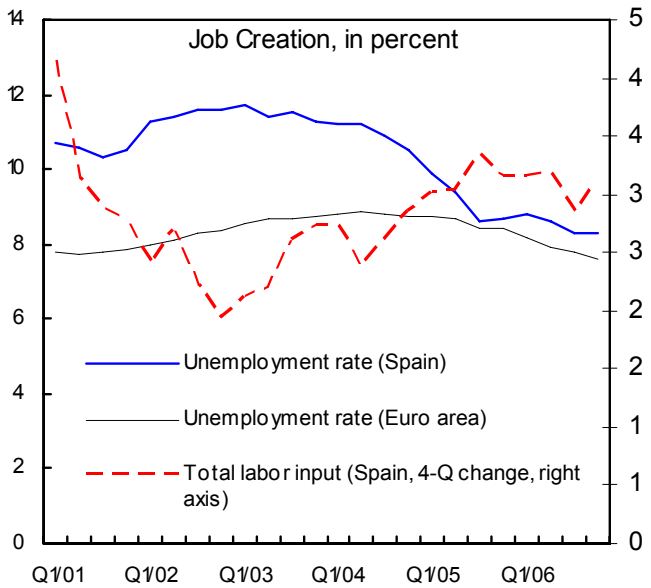

...and growth began to rebalance.

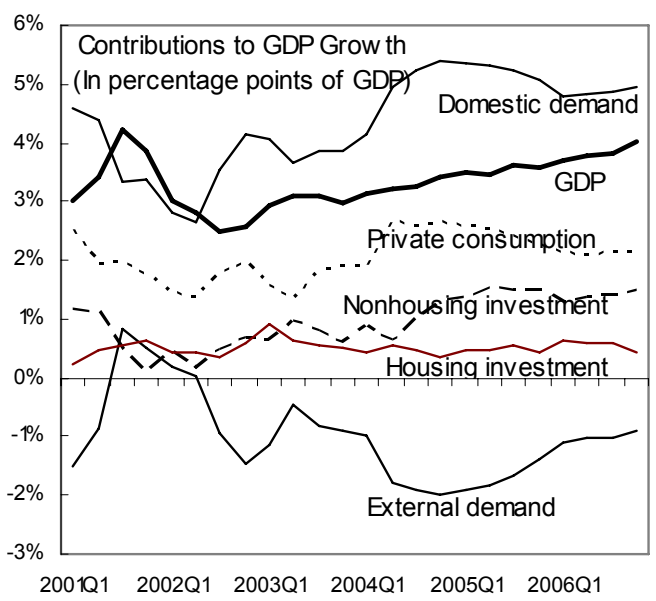

...propitiated a productivity upturn.

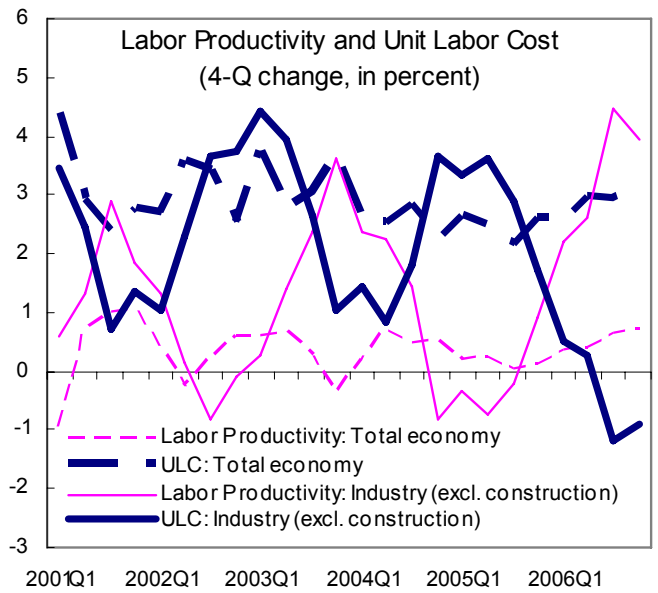

Oil price declines reduced the inflation differential.

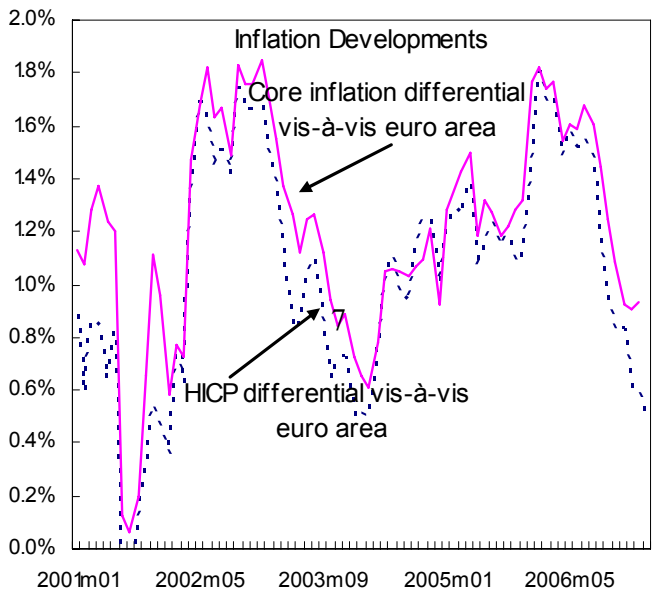

Sources: INE; Bank of Spain; OECD; Eurostat; WEO; and IMF staff calculations. 
Figure 2. Spain: Deteriorating Competitiveness

Current account continues to deteriorate.

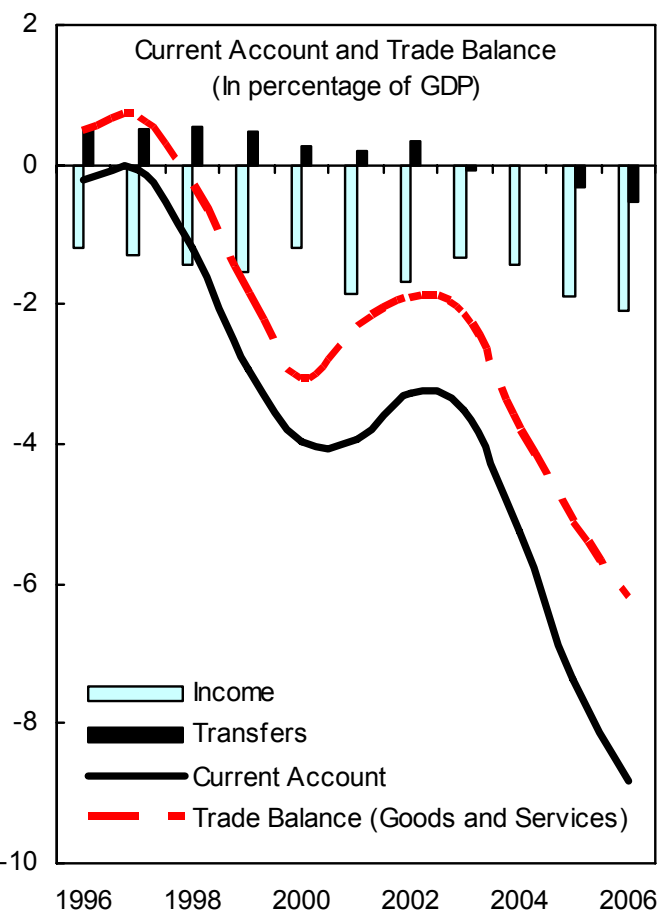

Export growth has lagged euro area's (EA) since 2004.

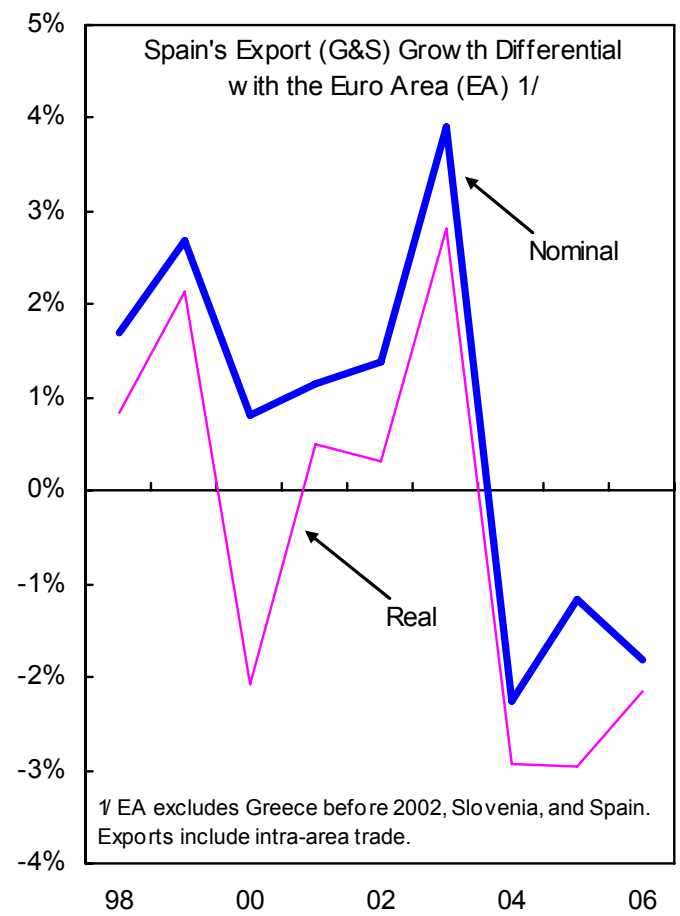

About 1/3 cannot be explained by cyclical factors or oil prices.

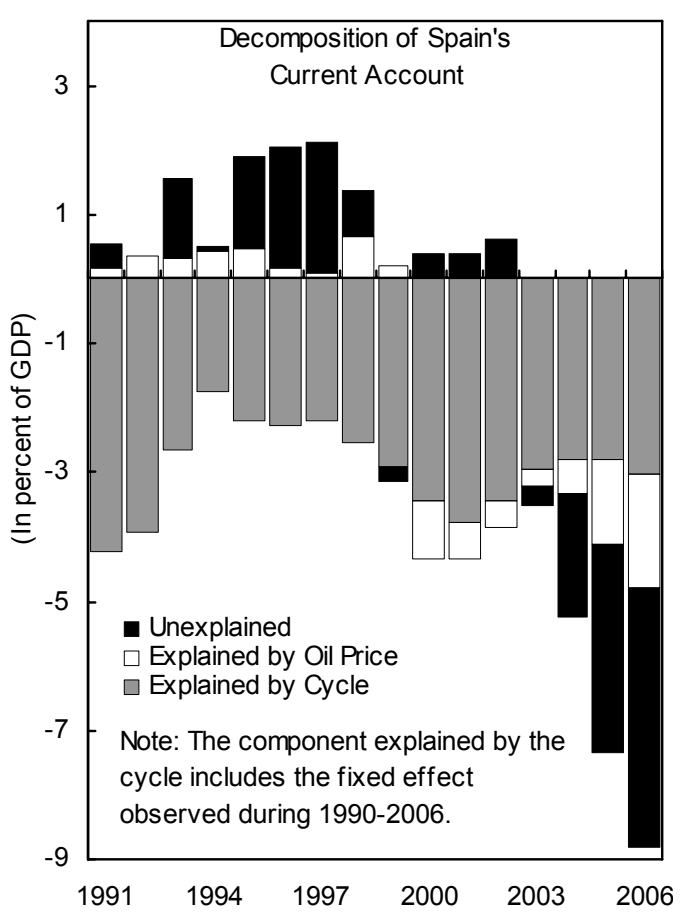

REER has appreciated.

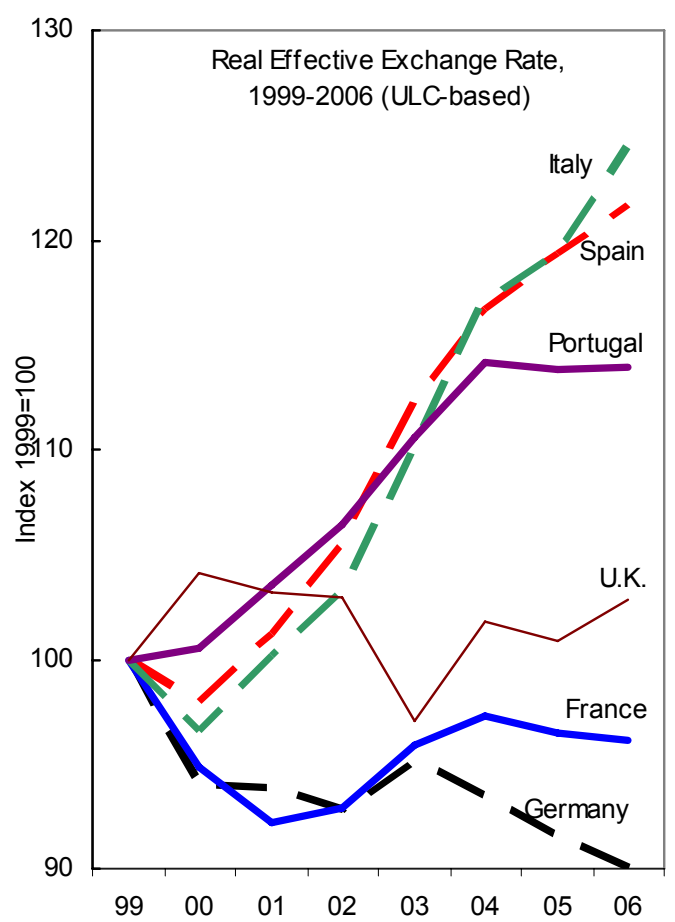


Figure 2. Spain: Deteriorating Competitiveness (concluded)

Manufacturing ULC growth has been higher than EA's. Export margin growth has been lower than EA's.
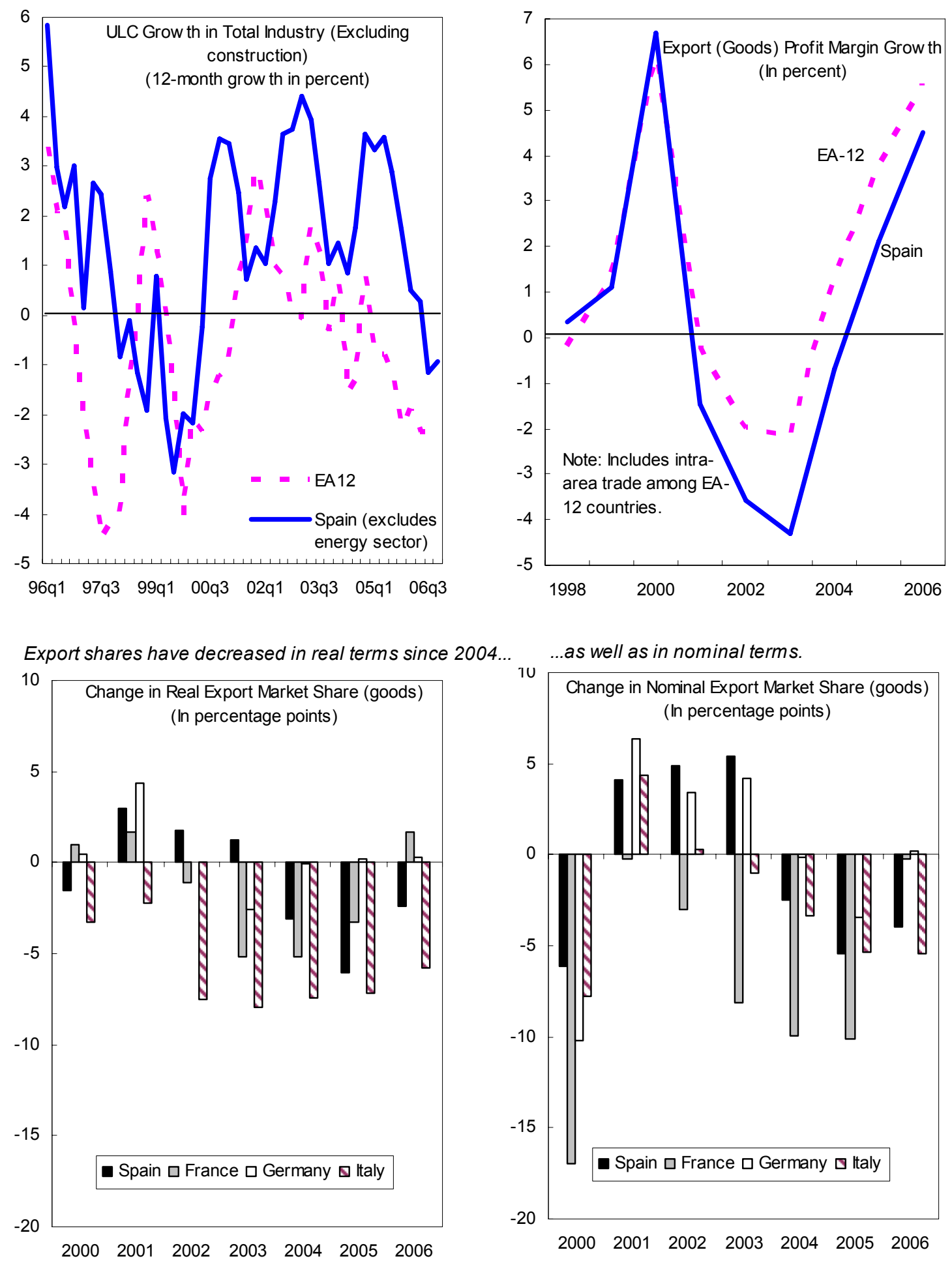

Sources: Bank of Spain; INE; Eurostat; IMF WEO, International Financial Statistics, and Global Data Source; and IMF staff estimates. 
Figure 3. Spain: Private Sector Indebtedness
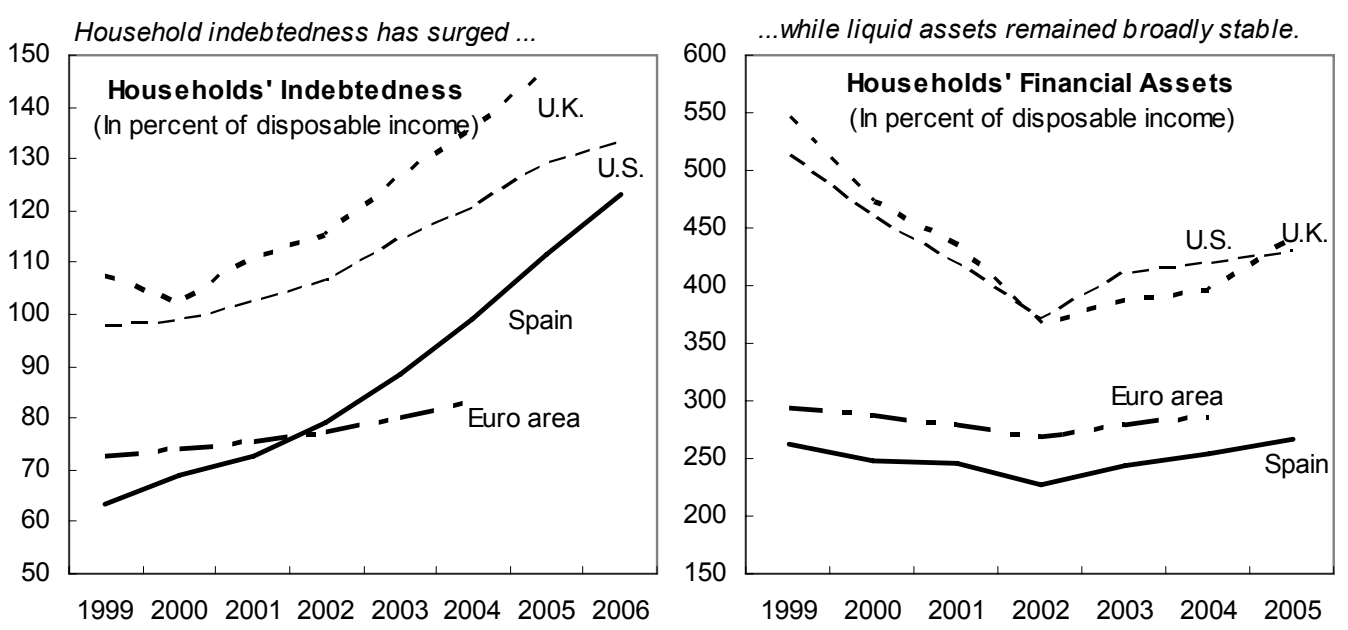

Rising insterest rates and debt accumulation 15.0 increased households' financial burden.

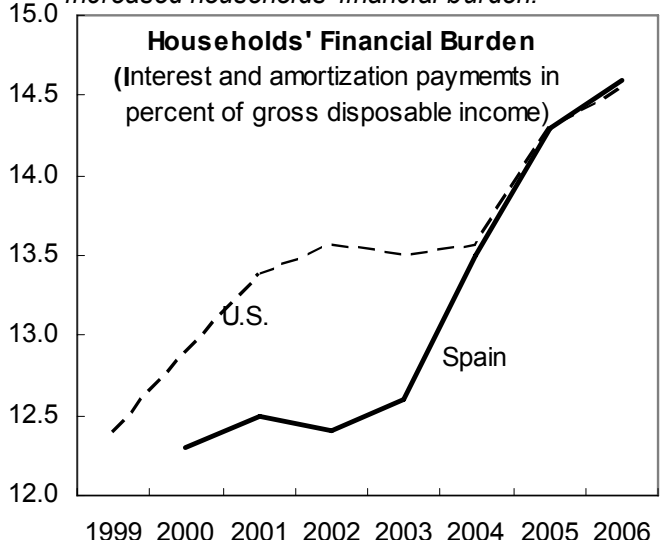

Low and middle-income households appear particularly indebted.
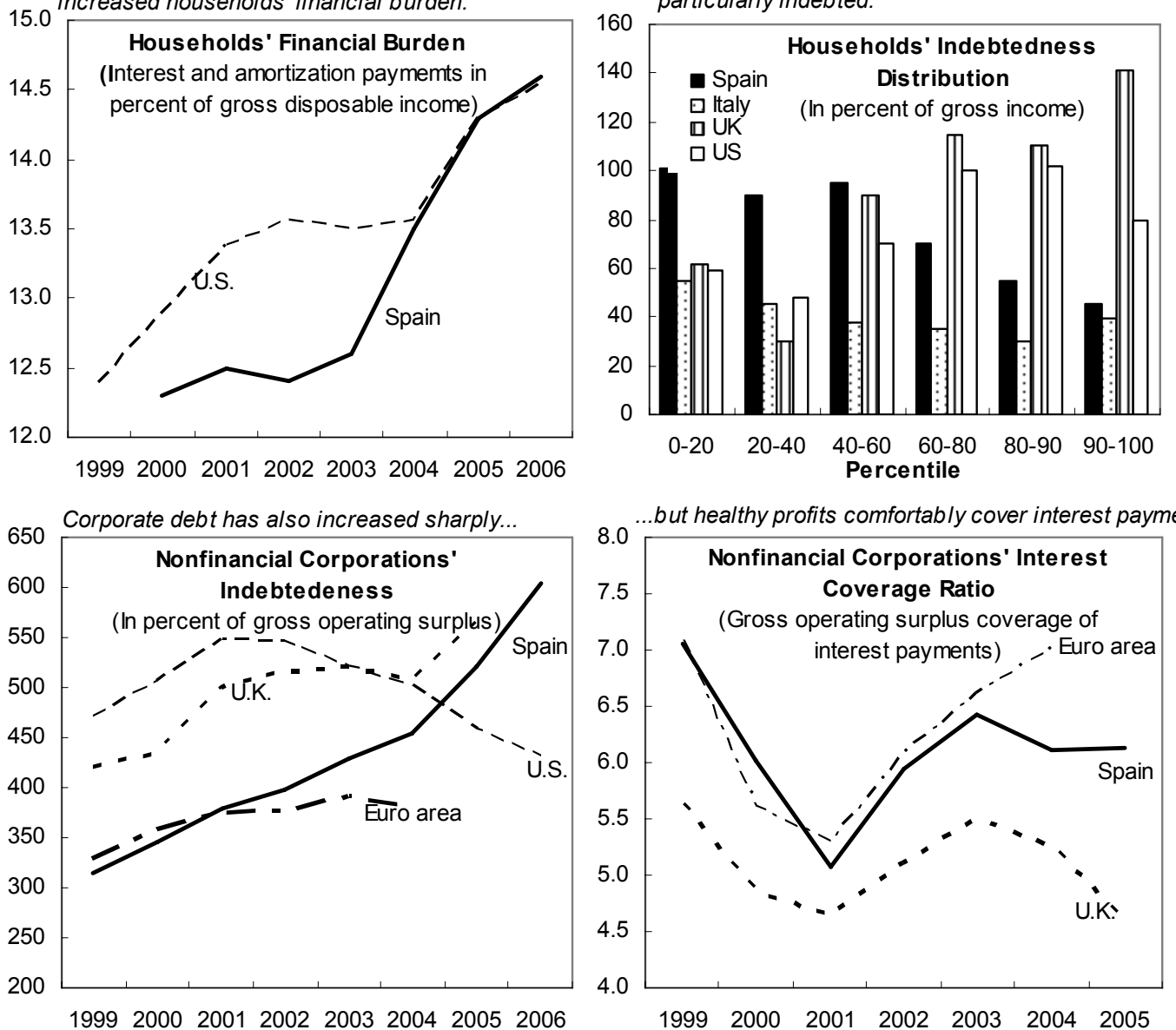

Sources: Bank of Spain; Eurostat; U.S. Federal Reserve; and U.S. Bureau of Economic Analvsis. 


\section{There was nonetheless agreement that policies needed to address the root causes} of the external imbalance and ensure a continuation of growth over the medium term. The discussions (in the context of a streamlined Article IV consultation) centered on the required policy response - containing demand and expanding supply_-building on past Fund advice. There was concurrence on the direction and main components of this response, though less so on the pace of implementation, given the different appreciation of the risks and the electoral calendar. ${ }^{2}$

Box 1. Implementation of Fund Policy Recommendations

The direction of policies remains broadly consistent with Fund recommendations. The fiscal stance tightened in 2006, as advised by the Fund - albeit based on revenue buoyancy rather than expenditure restraint. The authorities' structural reform program under the Lisbon agenda is generally well designed, but liberalization of labor and sensitive product markets has lagged. The authorities have consistently maintained strong financial sector prudential policies.

\section{Fiscal Policy: Preserving Budgetary Stability While Tempering Demand}

\section{Revenue buoyancy has strengthened public finances, but primary spending is} rising steadily. Higher-than-budgeted revenues (notably corporate and capital gains taxes) have been devoted to raising the surplus (1.8 percent of GDP in 2006), reducing debt (to below 40 percent of GDP), and building up the social security reserve fund (to 4 percent of GDP). However, primary spending (with a higher estimated impact on demand than revenue) rose by about 0.4 percentage points of GDP in both 2005 and 2006, driven by investment and rising regional government spending. Whereas the official forecast of a general government surplus of 1 percent of GDP in 2007 is likely to be exceeded, as in past years, staff considered that the combined effect of the 2006 tax reform, regional tax-cutting initiatives, and planned additional spending is likely to result in an untimely procyclical stimulus in 2007-08 (assuming unchanged policies). The authorities were more sanguine about structural revenue strength and thought that spending growth at the territorial level might moderate with respect to 2006, as the electoral spending cycle unwound.

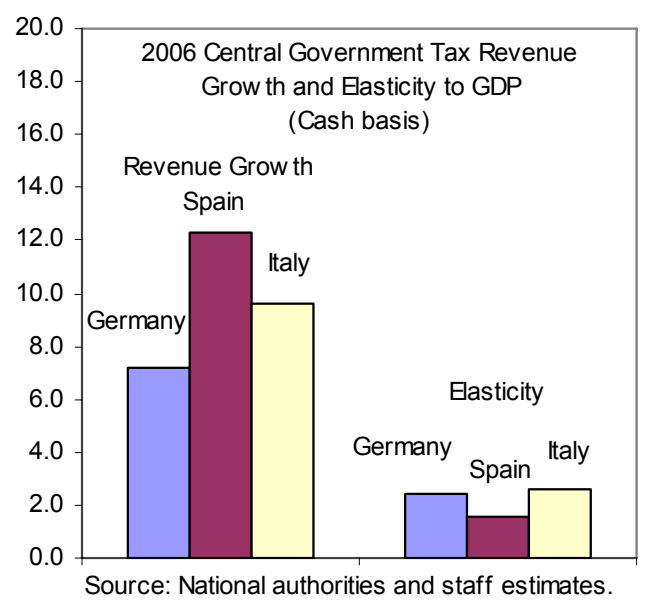

\footnotetext{
${ }^{2}$ Regional and local elections in May 2007, and parliamentary elections by March 2008.
} 
General Government Fiscal Operations

(In percent of GDP)

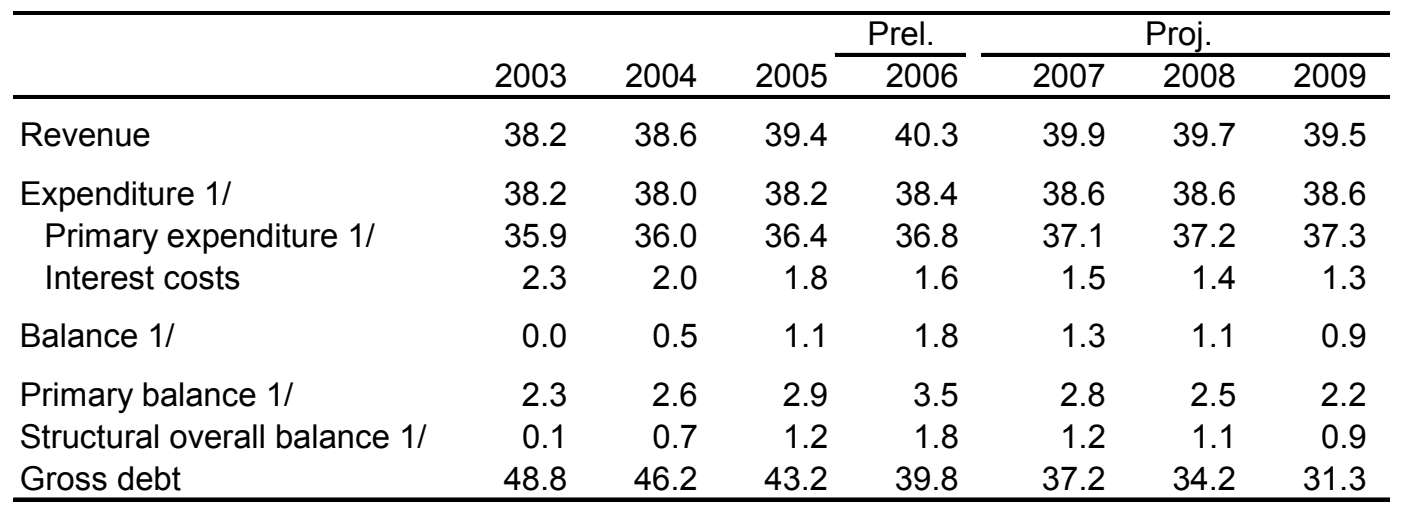

Sources: Authorities and IMF staff estimates.

1/ Calculations exclude one-off expenditure amounting to 0.7 percent of GDP in 2004.

6. For 2008 - the first year of application of the new Budget Stability Law-the authorities broadly shared staff's call for a countercyclical spending stance, but budget preparations have yet to start. With GDP growth projected to exceed 3 percent, the new Law requires the central and territorial governments to be in surplus . ${ }^{3}$ While the Law does not specify either the level or the allocation of the surplus among the different levels of government, the authorities concurred on the need for all levels of government, including the regions (in balance in 2006, despite buoyant revenues), to contribute to that outcome. In the same vein, they intend to apply strictly the Law's provisions governing the possible exclusion of certain capital expenditure from the targeted balance. As for the central government, the authorities viewed staff's call to set the expenditure ceiling so as to keep primary spending constant in relation to GDP as useful encouragement of restraint, but were not in a position to commit at this stage of budget preparations. While it was noted that a minority government might have difficulty in obtaining approval of a tight budget at the end of its term, the wide support for budgetary stability - including from parliamentarians and trade unions - and the absence of calls to "spend" the fiscal surplus provided encouragement.

\section{Mechanisms to ensure fiscal discipline in a highly decentralized system need} strengthening. With extensive decentralization, strengthened transparency and monitoring (in line with 2005 fiscal ROSC recommendations) remain the most effective means to secure fiscal discipline at the regional and local government levels - who now account for over

\footnotetext{
${ }^{3}$ The Law establishes a fiscal balance (for the general government excluding social security) for output growth between 2 and 3 percent; a surplus for growth above 3 percent; and a deficit of up to 1 percent of GDP (threefourths of which allocated to the regions) for growth below 2 percent. See IMF Country Report No. 06/211.
} 
75 percent of government spending, excluding social security. Despite progress, disclosure practices remain insufficient to prompt early identification of fiscal profligacy, elicit public censure, and stimulate corrective action. Weak areas include insufficient reporting of offbudget capital spending (via public enterprises and entities, public-private partnerships, etc.) and long lags in the publication of comparable, national accounts-based data for territorial governments. The authorities highlighted continuing efforts in these areas, including an ongoing census of all regional public entities. In a similar vein, given successive budgets' emphasis on "productive expenditure" (R\&D, infrastructure, etc.), staff called for a thorough review of the efficiency of such spending; the authorities noted the creation of a government agency that included that function. Given the key role of peer pressure in a decentralized system, staff also saw a useful role for independent assessments of fiscal policy plans and outturns at the various levels of government. Finally, with the long-term rise in age-related public spending currently estimated at $81 / 2$ percentage points of GDP (by 2050), preserving budgetary stability will require further pension reform, beyond that agreed in 2006-a point recognized by the authorities.

\section{RAISING SuPPLy CAPACITY AND IMPROVING COMPETITIVENESS}

8. Several key pieces of legislation, including a reform of the competition authority, are pending. The draft Competition Law strengthens the powers and independence of the competition authority and limits the government's capacity to overrule its merger decisions. It also includes potentially powerful new features such as an advocacy mandate, a leniency ("whistle-blower") policy, and parliamentary hearings for nominees. Staff welcomed these features but, against the background of a protracted takeover bid in the energy sector that had led the EU Commission to initiate two infringement proceedings against Spain, it emphasized the importance of a clearer political commitment by the government to contestable and open markets, and of greater independence of the sectoral regulators from their relevant ministries. In other areas, the authorities noted as priorities deregulation of energy tariffs and transposition of the EU Takeover Directive. They also saw implementation of the EU Services Directive as offering an opportunity to open sheltered markets and had centered its coordination in the Ministry of the Economy. 
Figure 4. Spain: Structural Issues

Domestic markets are among the most restricted...
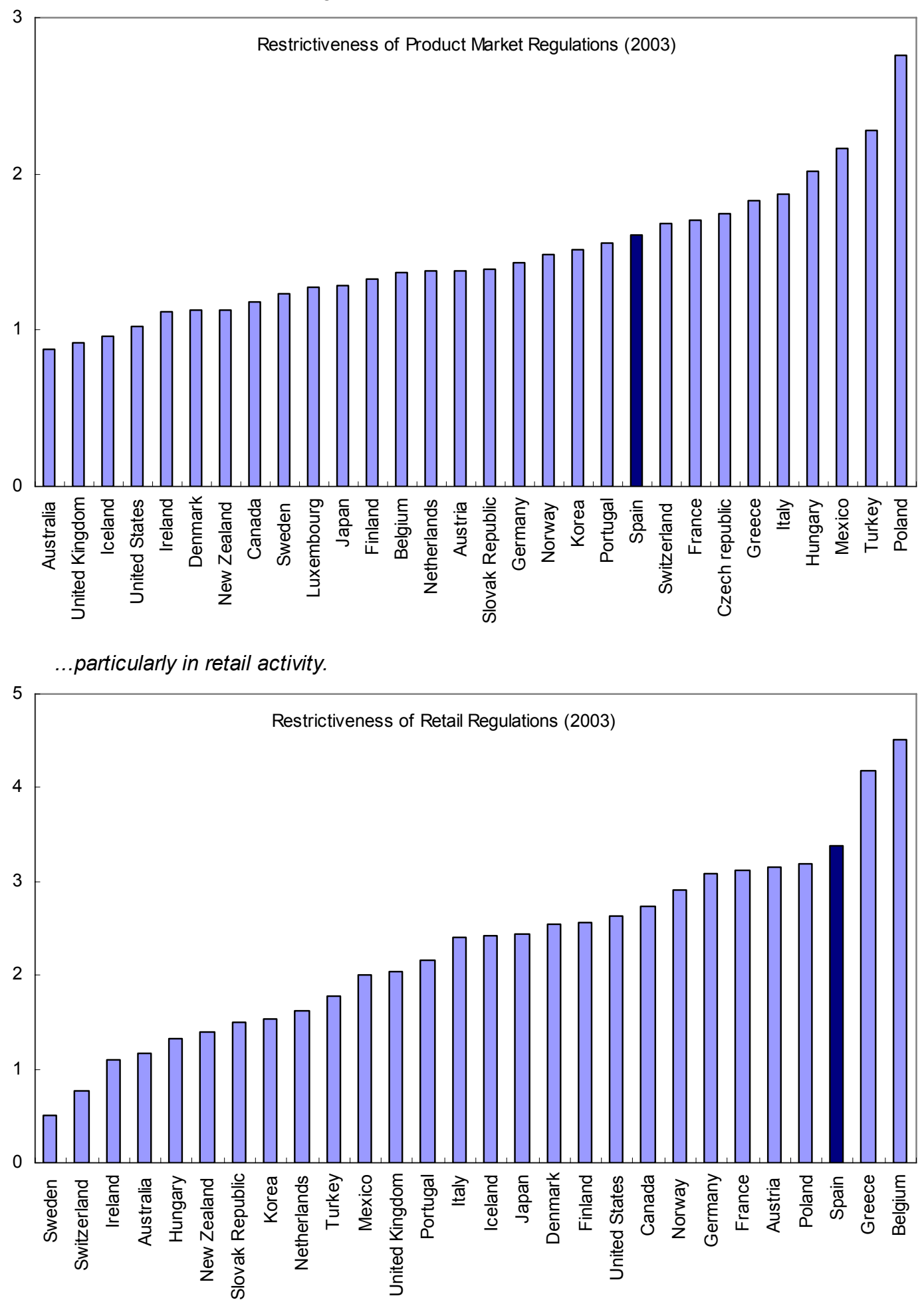
Figure 4. Spain: Structural Issues (concluded)

Also the competition framework is relatively not conducive to competition but is being reformed.

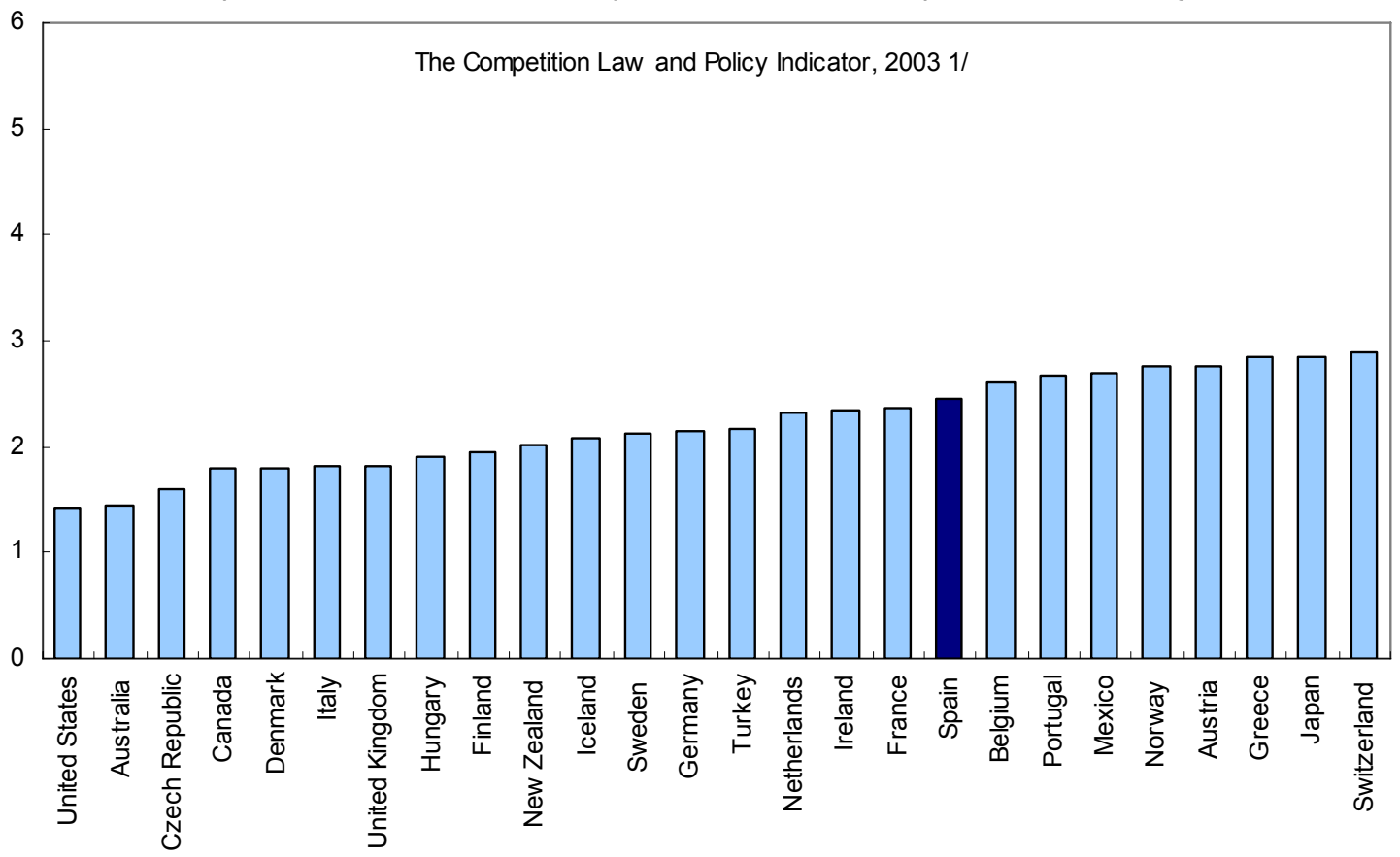

Pricing power in sheltered markets has been an inflationary factor.

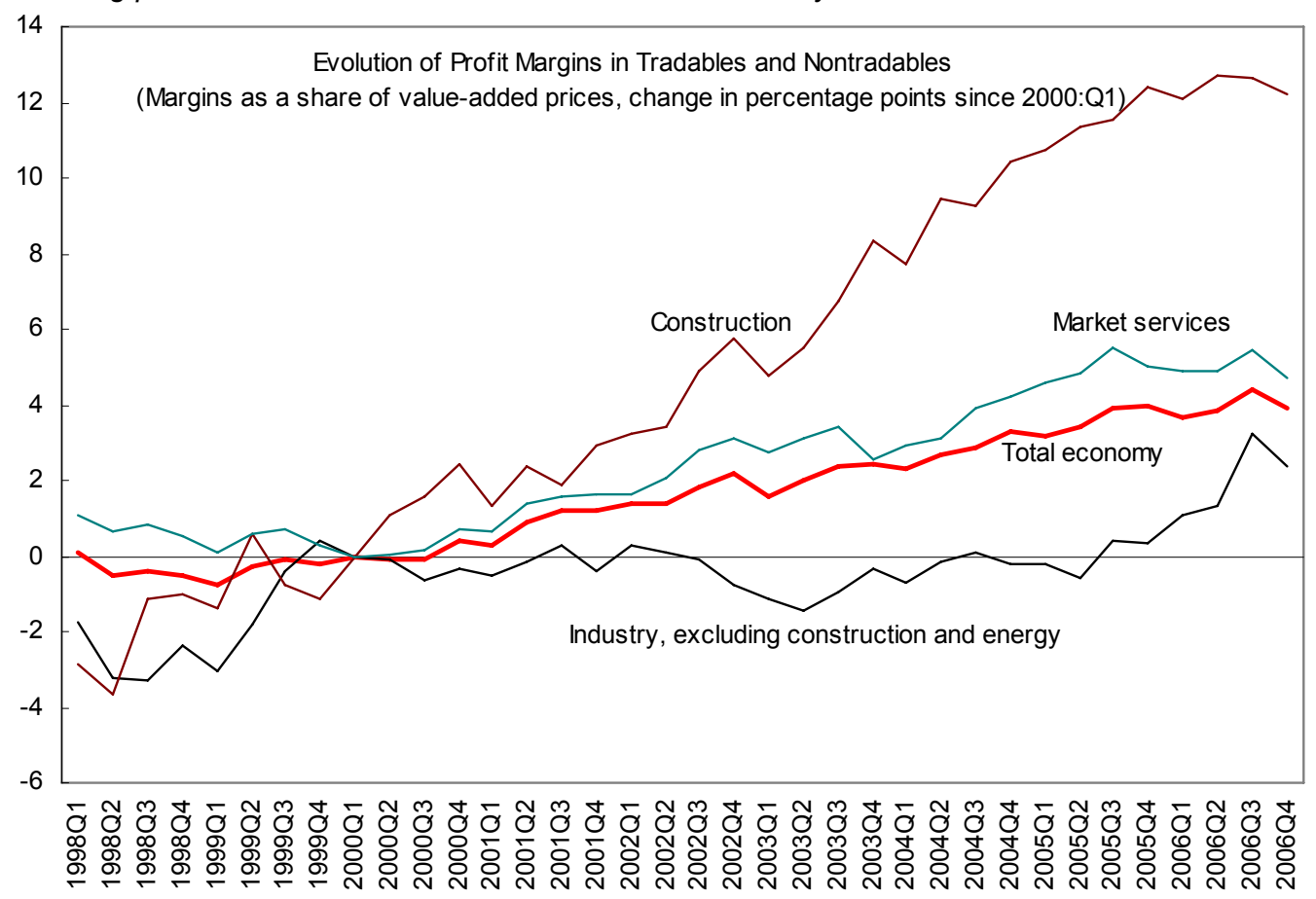

Source: INE, National Accounts; OECD; Høj et al. (2007), forthcoming; IMF staff estimates.

1. Indicator scale of 0-6 with 6 designating an overall framework least conducive to competition. 
9. The authorities' National Reform Program under the Lisbon agenda is broadly appropriate; determined implementation remains key. Implementation has focused on stepping up government provision of public goods (infrastructure, education) and activities with growth-enhancing externalities (R\&D) - areas where there is a broad consensus. In contrast, progress in overcoming special interests, to foster competition in sheltered markets and more flexibility in labor markets, has lagged. The authorities view the 2006 labor market reform, which staff considered limited, as a

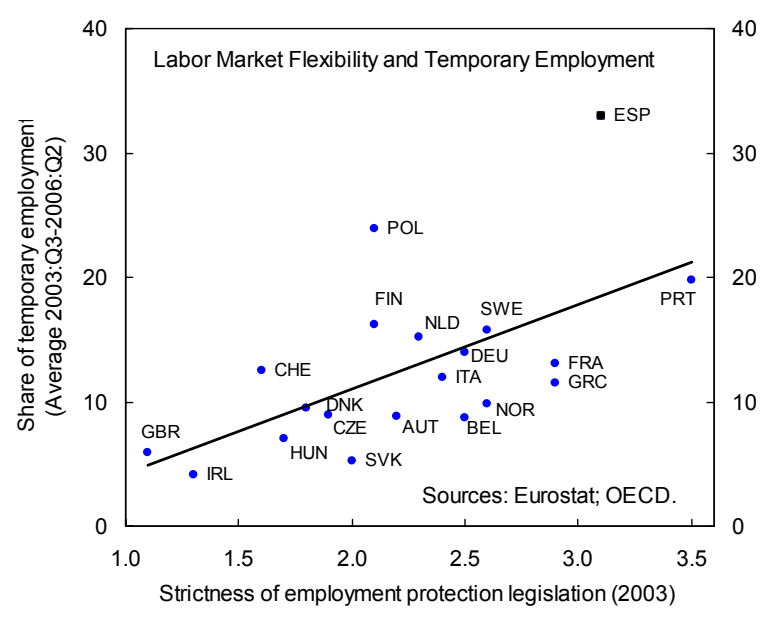
step in a continuous process of reforms requiring consensus that, like pension reform, would need to continue in the next legislature.

\section{KeEPING The Financial SECTOR STRONG}

\section{The Bank of Spain has remained vigilant in the face of continued strong credit}

growth. 2006 was another year of strong profitability and dynamism in the financial sector. Nevertheless, while loan losses remain at very low levels and provisions are high, rapid credit growth and large exposures to the real estate sector warrant continued supervisory attention. There was agreement however that the risks associated with high levels of private indebtedness relate mainly to the growth outlook rather than to financial stability, which the 2006 FSAP showed to be resilient to a range of large adverse shocks. Moreover, there is no parallel to the U.S. subprime market in Spain. Mortgages are predominantly issued by banks subject to tight prudential supervision and strict lending standards. Nondeposit-taking companies ("debt consolidation" companies) represent a tiny fraction of the market and act primarily as brokers between debtors and creditors, raising consumer protection issueswhich the authorities intend to address - rather than solvency concerns.

11. Preparations for MiFID and Basel II are advancing. Notwithstanding legislative delays, the authorities expressed confidence that both measures would be effective within their set deadlines. Banks' large industrial participations would be subject to the strictest Basel II requirements - an FSAP recommendation; this appears to have contributed to significant divestments during 2006. In contrast, the planned transfer of insurance supervision from the Ministry of Economy to the central bank (solvency issues) and the Securities Commission (consumer protection) - in line with FSAP recommendations - has stalled (Table 6). Finally, an active public debate is underway on improving savings banks' governance, and the authorities saw scope for future progress in this area. 


\section{Staff Appraisal}

12. The Spanish economy again grew strongly in 2006, while showing signs of the awaited rebalancing of growth. Besides strong GDP growth, the performance also comprised rapid employment expansion, a significant deceleration in inflation, a pickup in manufacturing productivity, and a strong fiscal outturn. Welcome signs of a rebalancing of growth compared to the recent past include a slowing in consumption and housing and a strengthening of exports - although the negative contribution of the external sector remains large.

13. These positive developments enhance prospects for a soft landing, but downside risks posed by rising indebtedness remain pronounced. Growth is expected to settle close to potential in 2007-08, but the already very large current account deficit is set to widen further, to $9 \frac{1}{2}-10$ percent of GDP. The counterpart to this deficit is growing private sector indebtedness, whose accumulation clearly cannot go on indefinitely. The risk is that agents may adjust their balance sheets more rapidly than foreseen and that regaining competitiveness within EMU - given significant domestic market rigidities that hinder resource reallocation - may entail a protracted period of weak activity.

14. To forestall adverse scenarios and ensure the sustainability of continued growth, three priorities need to orient policies: safeguarding budgetary stability while tempering demand; raising supply capacity and improving competitiveness; and keeping the financial sector strong.

15. A more resolute, expenditure-based countercyclical fiscal stance would be consistent with the new Budget Stability Law and help contain demand. The mediumterm orientation of the Law requires acting now, in "good times," to avoid the entrenchment of difficult-to-reverse primary spending dynamics. The Law's first year of implementation2008 - should be exemplary. To this end, the central government expenditure ceiling should keep primary spending constant as a share of GDP, and the regional governments should target an ambitious surplus, reflecting their share of the permissible deficit in low-growth periods.

16. Preserving budgetary stability will require substantial strengthening of fiscal accountability as well as further pension reform. Securing fiscal discipline in a highly decentralized system requires far greater progress in fiscal transparency of territorial governments, with timely publication of comparable, national accounts-based data. Improvements in the reporting of off-budget operations are also required at all levels of government. The next legislature should aim for an early revival of reforms to place the pension system on a sustainable long-term path.

17. Competition-promoting efforts should be stepped up and underpinned by a strengthened political commitment to promote contestable markets. The draft 
Competition Law introduces valuable institutional measures that will need proactive implementation. The independence of sectoral regulators should also be enhanced by an arm's length relationship with sectoral ministries. Work on transposing the EU Services Directive should be accelerated as it holds the potential to open up still highly sheltered sectors throughout Spain. Finally, while unprecedented large immigration flows have imparted a de facto flexibility to the labor market, this will need to be consolidated by reforms.

\section{The financial sector has recorded another strong year, but the Bank of Spain's}

continued vigilance is well-placed. The main risks relate to rapid credit growth and loan concentration in the real estate sector. Spain's support for the process of European financial integration should be reflected in a timely passage of the Markets in Financial Instruments Directive. Basel II legislation - with its welcome application of conservative approaches to banks' industrial holdings - should similarly proceed forthwith. The proposed spin-off of insurance supervision from the Ministry of Economy has clear merits and should be revived. Finally, with savings banks acquiring an increasingly prominent role, the time is ripe for improvements in their governance, enhancing their exposure to market discipline.

19. It is recommended that the next consultation be held on the 12-month cycle. 
Table 1. Spain: Main Economic Indicators, 2002-08

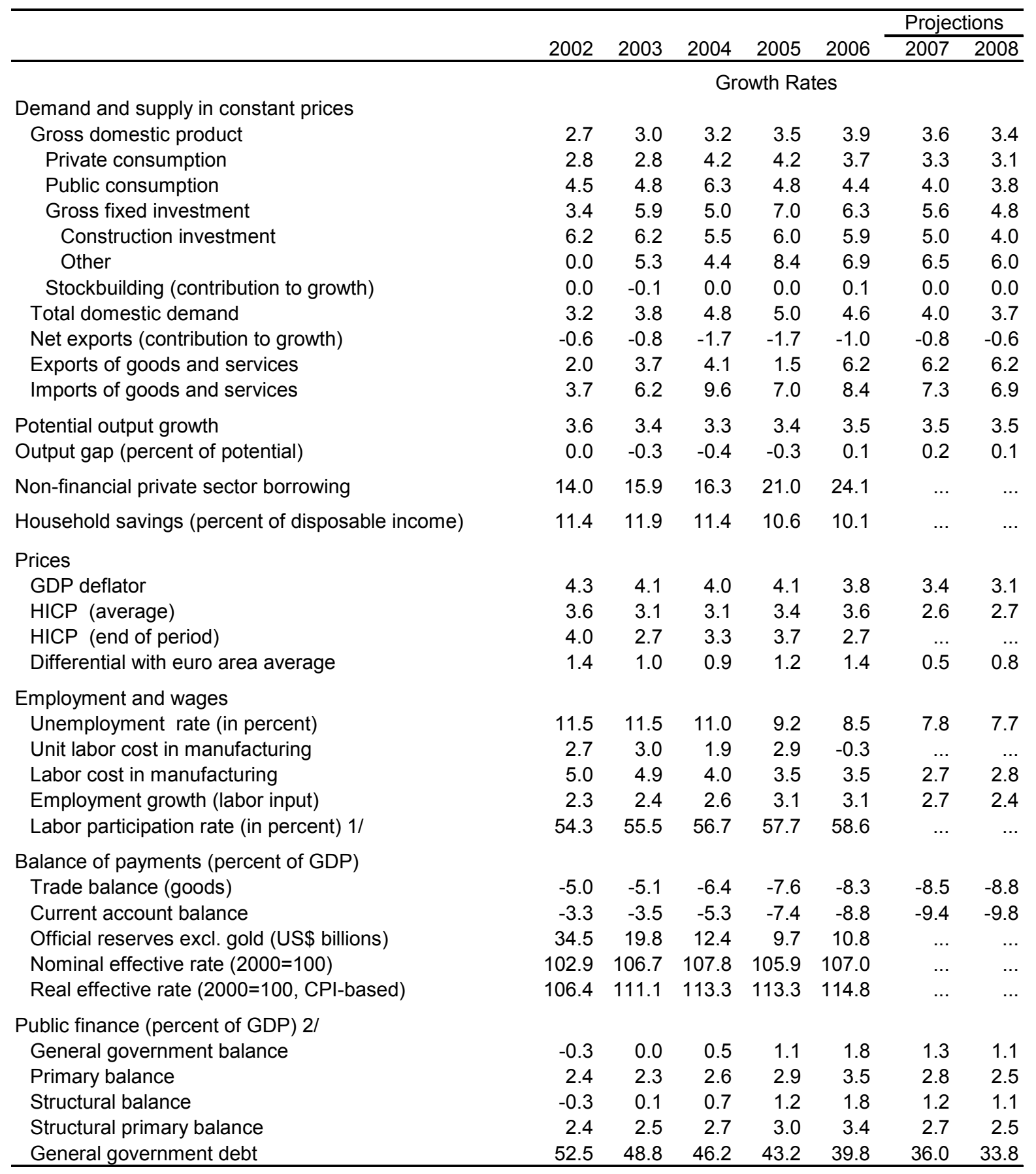

Sources: IMF, World Economic Outlook; data provided by the authorites; and IMF staff estimates.

1/ Based on national definition (i.e., the labor force is defined as people older than 16).

2/ Calculations exclude one-off expenditure amounting to 0.7 percent of GDP in 2004. 
Table 2. Spain: Fiscal Accounts, 2003-08

(In percent of GDP)

\begin{tabular}{|c|c|c|c|c|c|c|}
\hline & & & & Prel. & Projec & \\
\hline & 2003 & 2004 & 2005 & 2006 & 2007 & 2008 \\
\hline Total revenues & 38.2 & 38.6 & 39.4 & 40.3 & 39.9 & 39.7 \\
\hline Current revenues & 37.5 & 37.7 & 38.6 & 39.7 & 39.4 & 39.2 \\
\hline Indirect taxes & 11.6 & 12.0 & 12.2 & 12.4 & 12.3 & 12.3 \\
\hline Direct taxes & 10.1 & 10.2 & 10.9 & 11.7 & 11.4 & 11.5 \\
\hline Social security contributions & 13.0 & 13.0 & 13.0 & 13.0 & 13.0 & 12.9 \\
\hline Other current revenues & 2.8 & 2.6 & 2.5 & 2.6 & 2.7 & 2.5 \\
\hline Capital Revenue & 0.7 & 0.9 & 0.8 & 0.6 & 0.5 & 0.5 \\
\hline Total expenditures 1/ & 38.2 & 38.0 & 38.2 & 38.4 & 38.6 & 38.6 \\
\hline Primary expenditures & 35.9 & 36.0 & 36.4 & 36.8 & 37.1 & 37.2 \\
\hline Current expenditures & 31.2 & 31.6 & 31.6 & 31.6 & 32.0 & 32.1 \\
\hline of which wages and salaries & 10.1 & 10.1 & 10.0 & 10.0 & 10.0 & 10.0 \\
\hline Capital expenditures $1 /$ & 4.7 & 4.4 & 4.8 & 5.2 & 5.1 & 5.1 \\
\hline of which Gross fixed capital formation & 3.6 & 3.4 & 3.6 & 3.9 & 3.9 & 3.9 \\
\hline Interest payments & 2.3 & 2.0 & 1.8 & 1.6 & 1.5 & 1.4 \\
\hline Primary balance & 2.3 & 2.6 & 2.9 & 3.5 & 2.8 & 2.5 \\
\hline Overall balance 1/ & 0.0 & 0.5 & 1.1 & 1.8 & 1.3 & 1.1 \\
\hline Central government $1 /$ & 0.4 & -0.5 & 0.4 & 0.8 & 0.6 & 0.5 \\
\hline Territorial governments & -0.7 & 0.0 & -0.4 & -0.2 & -0.2 & 0.0 \\
\hline Social security & 1.0 & 1.0 & 1.1 & 1.2 & 0.9 & 0.6 \\
\hline Government debt & 48.8 & 46.2 & 43.2 & 39.8 & 36.0 & 33.8 \\
\hline Memorandum items: & & & & & & \\
\hline Structural primary balance $1 /$ & 2.5 & 2.7 & 3.0 & 3.4 & 2.7 & 2.5 \\
\hline Structural balance 1/ & 0.1 & 0.7 & 1.2 & 1.8 & 1.2 & 1.1 \\
\hline
\end{tabular}

Sources: Cuentas Financieras, Bank of Spain; IGAE ;and IMF staff projections.

1/ Calculations exclude one-off expenditure amounting to 0.7 percent of GDP in 2004. 
Table 3. Spain: Indicators of External and Financial Vulnerability, 2002-06

(In percent of GDP unless otherwise indicated)

\begin{tabular}{|c|c|c|c|c|c|}
\hline & 2002 & 2003 & 2004 & 2005 & 2006 \\
\hline \multicolumn{6}{|l|}{ External indicators } \\
\hline Exports (annual percent change, in U.S. dollars) & 8.1 & 24.0 & 16.8 & 6.4 & 10.5 \\
\hline Imports (annual percent change, in U.S. dollars) & 7.0 & 25.2 & 23.9 & 11.4 & 14.0 \\
\hline Terms of trade (annual percent change) & 2.8 & 1.5 & -0.8 & 0.7 & 0.3 \\
\hline Current account balance (settlements basis) & -3.3 & -3.5 & -5.3 & -7.4 & -8.8 \\
\hline Capital and financial account balance & 3.2 & 3.5 & 5.2 & 7.5 & 8.4 \\
\hline Of which: Inward portfolio investment (debt securities, etc.) & 4.9 & 5.0 & 13.4 & 15.1 & 18.9 \\
\hline Inward foreign direct investment & 5.7 & 2.9 & 2.4 & 2.0 & 1.4 \\
\hline Other investment liabilities (net) & 1.8 & 6.6 & -2.7 & 3.4 & -4.3 \\
\hline Official reserves (in U.S. dollars, billions, end-of-period) & 34.5 & 19.8 & 12.4 & 9.7 & 10.8 \\
\hline Central Bank foreign liabilities (in U.S. dollars, billions) & 69.6 & 86.6 & 103.6 & 118.1 & 135.3 \\
\hline Foreign assets of the financial sector (in U.S. dollars, billions) & 342.5 & 427.3 & 527.5 & 689.9 & 801.3 \\
\hline Foreign liabilities of the financial sector (in U.S. dollars, billions) & 587.5 & 812.2 & 1033.3 & 1294.9 & 1561.7 \\
\hline Official reserves in months of imports & 2.1 & 0.9 & 0.5 & 0.3 & 0.3 \\
\hline Net international investment position & -31.9 & -37.6 & -42.9 & -46.0 & -57.9 \\
\hline Gross liabilities & 133.3 & 141.3 & 152.7 & 170.3 & 191.6 \\
\hline Gross assets & 101.4 & 103.7 & 109.8 & 124.3 & 133.7 \\
\hline Public debt held by foreigners $1 /$ & 22.3 & 18.7 & 20.2 & 19.7 & 19.7 \\
\hline \multicolumn{6}{|l|}{ Financial market indicators } \\
\hline Public sector debt (Maastricht definition) & 52.5 & 48.8 & 46.2 & 43.2 & 39.8 \\
\hline Three-month T-bill yield & 3.3 & 2.2 & 2.2 & 2.2 & 3.3 \\
\hline Three-month T-bill yield (real) & -0.2 & -0.9 & -0.9 & -1.2 & -0.3 \\
\hline Stock market index (general, december 1985=100) & 634.0 & 807.9 & 959.1 & 1156.2 & 1554.9 \\
\hline Share prices of financial institutions (december 2004=1000) & 703.7 & 918.5 & 1000.0 & 1226.5 & 1654.3 \\
\hline Spread of three-month T-bills with Germany (percentage points, end-of-period) & 0.4 & 0.2 & 0.2 & 0.2 & 0.2 \\
\hline \multicolumn{6}{|l|}{ Financial soundness indicators (core set) (in percent) 2/ } \\
\hline Regulatory capital to risk-weighted assets & 12.5 & 12.6 & 12.2 & 12.0 & 11.9 \\
\hline Regulatory tier I capital to risk-weighted assets & 8.6 & 8.5 & 8.0 & 8.1 & 7.5 \\
\hline Nonperforming credit to total gross credit $3 /$ & 1.0 & 0.9 & 0.7 & 0.6 & 0.6 \\
\hline Nonperforming credit net of provisions to total capital 4 / & 1.6 & 0.5 & -1.0 & -4.7 & -1.2 \\
\hline Credit to residents to total credit & 73.6 & 75.9 & 68.3 & 65.7 & 69.1 \\
\hline Credit to nonresidents to total credit & 26.4 & 24.1 & 31.7 & 34.3 & 30.9 \\
\hline \multicolumn{6}{|l|}{ Of which (by region of residence): } \\
\hline European Union (except Spain) & 11.4 & 11.9 & 20.0 & 20.9 & 18.3 \\
\hline Latin America and the Caribbean & 11.5 & 9.2 & 8.2 & 9.1 & 8.1 \\
\hline Credit institutions lending (to non financial sector) & 10.4 & 14.3 & 15.4 & 23.0 & 19.0 \\
\hline Return on assets & 0.9 & 0.9 & 1.0 & 0.9 & 1.0 \\
\hline Return on equity & 12.1 & 13.2 & 14.5 & 16.9 & 19.9 \\
\hline Interest margin to gross income & 70.8 & 68.8 & 68.9 & 58.9 & 56.5 \\
\hline Noninterest expense to gross income $5 /$ & 59.8 & 58.0 & 55.7 & 52.8 & 47.6 \\
\hline Liquid assets to total assets (liquid asset ratio) $6 /$ & 30.9 & 30.3 & 27.5 & 31.9 & 27.5 \\
\hline Liquid assets to short-term liabilities $7 /$ & 70.2 & 67.9 & 66.0 & 76.5 & 72.7 \\
\hline Net open position in foreign exchange to tier I capital & 13.5 & 8.6 & 11.9 & 11.7 & 12.2 \\
\hline Indebtedness of nonfinancial corporations (debt/gross operating surplus) $8 /$ & 397.8 & 430.1 & 453.4 & 521.0 & 603.2 \\
\hline
\end{tabular}

Sources: Bank of Spain, Economic and Statistical Bulletins; CNMV; data provided by the authorities; and IMF, International Financial Statistics.

1/ Data for 2006 refers to the third quarter.

2/ Deposit-taking institutions comprise commercial, savings, and cooperative banks.

$3 /$ Total gross credit does not include cash and central bank.

4/ Nonperforming credit net of specific provisions and those general and statistical provisions not included in tier 2 capital to total regulatory capital.

5/ Data series starting December 2005 denote the implementation of new accounting rules (IFRS).

6/ Excludes equity investments and fixed income portfolio instruments.

7/ Includes both fixed and variable income portfolio instruments.

8/ Debt excludes non-interest obligations and financing provided by suppliers. 
Table 4. Spain: Balance of Payments, 2000-06

\begin{tabular}{|c|c|c|c|c|c|c|c|}
\hline & 2000 & 2001 & 2002 & 2003 & 2004 & 2005 & 2006 \\
\hline & \multicolumn{6}{|c|}{ In billions of euro } & \\
\hline Current account balance & -24.9 & -26.8 & -23.8 & -27.5 & -44.2 & -66.6 & -86.0 \\
\hline Trade balance & -19.2 & -15.6 & -13.9 & -16.5 & -31.9 & -46.3 & -60.4 \\
\hline Exports of goods & 125.6 & 131.2 & 134.8 & 139.8 & 149.0 & 156.4 & 172.1 \\
\hline Imports of goods & 165.8 & 169.8 & 171.3 & 179.6 & 202.6 & 225.3 & 252.7 \\
\hline Balance of nonfactor services & 21.0 & 23.0 & 22.6 & 23.3 & 21.8 & 22.6 & 20.1 \\
\hline Balance of factor income & -7.5 & -12.6 & -12.3 & -10.4 & -12.1 & -17.2 & -20.4 \\
\hline Balance of current transfers & 1.7 & 1.4 & 2.5 & -0.5 & -0.1 & -3.1 & -5.2 \\
\hline Capital account balance & 5.2 & 5.4 & 7.7 & 8.2 & 8.4 & 8.0 & 6.2 \\
\hline Financial account balance & 19.5 & 21.7 & 15.4 & 17.8 & 34.9 & 59.6 & 83.2 \\
\hline Foreign direct investment & -20.2 & -5.3 & 6.9 & -2.6 & -28.8 & -12.7 & -47.8 \\
\hline Gross inflows & 43.0 & 31.7 & 41.7 & 22.9 & 19.9 & 18.5 & 13.6 \\
\hline Gross outflows & 63.2 & 37.0 & 34.8 & 25.4 & 48.8 & 31.2 & 61.4 \\
\hline Portfolio & -1.4 & -18.9 & 4.2 & -41.8 & 80.8 & 40.5 & 172.1 \\
\hline Other investment & 35.9 & 44.7 & 12.8 & 52.0 & -22.4 & 30.3 & -42.3 \\
\hline Reserve assets & 5.2 & 1.2 & -8.5 & 10.2 & 5.2 & 1.5 & 1.2 \\
\hline \multirow[t]{2}{*}{ Errors and omissions } & 0.3 & -0.3 & 0.7 & 1.5 & 0.9 & -0.9 & -3.3 \\
\hline & \multicolumn{5}{|c|}{ In percent of GDP } & & \\
\hline Current account balance & -4.0 & -3.9 & -3.3 & -3.5 & -5.3 & -7.4 & -8.8 \\
\hline Trade balance of goods and services & -3.0 & -2.3 & -1.9 & -2.1 & -3.8 & -5.1 & -6.2 \\
\hline Exports of goods & 19.9 & 19.3 & 18.5 & 17.9 & 17.7 & 17.3 & 17.6 \\
\hline Imports of goods & 26.3 & 25.0 & 23.5 & 23.0 & 24.1 & 24.9 & 25.9 \\
\hline Balance of nonfactor services & 3.3 & 3.4 & 3.1 & 3.0 & 2.6 & 2.5 & 2.1 \\
\hline Balance of factor income & -1.2 & -1.8 & -1.7 & -1.3 & -1.4 & -1.9 & -2.1 \\
\hline Balance of current transfers & 0.3 & 0.2 & 0.3 & -0.1 & 0.0 & -0.3 & -0.5 \\
\hline Capital account balance & 0.8 & 0.8 & 1.1 & 1.0 & 1.0 & 0.9 & 0.6 \\
\hline Financial account balance & 3.1 & 3.2 & 2.1 & 2.3 & 4.1 & 6.6 & 8.5 \\
\hline Foreign direct investment & -3.2 & -0.8 & 0.9 & -0.3 & -3.4 & -1.4 & -4.9 \\
\hline Gross inflows & 6.8 & 4.7 & 5.7 & 2.9 & 2.4 & 2.0 & 1.4 \\
\hline Gross outflows & 10.0 & 5.4 & 4.8 & 3.3 & 5.8 & 3.4 & 6.3 \\
\hline Portfolio & -0.2 & -2.8 & 0.6 & -5.3 & 9.6 & 4.5 & 17.6 \\
\hline Other investment & 5.7 & 6.6 & 1.8 & 6.6 & -2.7 & 3.4 & -4.3 \\
\hline Reserve assets & 0.8 & 0.2 & -1.2 & 1.3 & 0.6 & 0.2 & 0.1 \\
\hline Errors and omissions & 0.0 & 0.0 & 0.1 & 0.2 & 0.1 & -0.1 & -0.3 \\
\hline
\end{tabular}

Source: Bank of Spain. 
Table 5. Spain: Medium-Term Projections of the Balance of Payments

\begin{tabular}{|c|c|c|c|c|c|c|c|c|}
\hline & 2005 & 2006 & 2007 & 2008 & 2009 & 2010 & 2011 & 2012 \\
\hline & \multicolumn{8}{|c|}{ In billions of euros } \\
\hline Current account & -66.6 & -86.0 & -98.0 & -109.0 & -117.7 & -124.1 & -130.7 & -137.0 \\
\hline Trade balance of goods and services & -46.3 & -60.4 & -63.7 & -70.1 & -74.1 & -76.5 & -78.7 & -81.4 \\
\hline Exports of goods and services & 231.8 & 254.0 & 278.0 & 303.6 & 330.9 & 360.0 & 391.0 & 423.7 \\
\hline Exports of goods & 156.4 & 172.1 & 182.6 & 198.9 & 216.4 & 234.9 & 254.8 & 275.8 \\
\hline Exports of services & 75.4 & 81.9 & 95.4 & 104.7 & 114.6 & 125.1 & 136.2 & 147.9 \\
\hline Imports of goods and services & -278.1 & -314.5 & -341.7 & -373.7 & -405.1 & -436.5 & -469.6 & -505.1 \\
\hline Imports of goods & -225.3 & -252.7 & -271.1 & -296.3 & -321.1 & -345.8 & -371.7 & -399.6 \\
\hline Imports of services & -52.8 & -61.8 & -70.6 & -77.4 & -84.0 & -90.7 & -97.9 & -105.5 \\
\hline Balance of factor income & -17.2 & -20.4 & -25.7 & -28.0 & -30.5 & -32.9 & -35.7 & -38.3 \\
\hline Balance of currents transfers & -3.1 & -5.2 & -8.6 & -10.9 & -13.1 & -14.7 & -16.4 & -17.3 \\
\hline Capital account & 8.0 & 6.2 & 5.2 & 5.6 & 4.7 & 5.0 & 4.0 & 4.2 \\
\hline Financial account & 59.6 & 83.2 & 92.8 & 103.4 & 113.0 & 119.1 & 126.7 & 132.8 \\
\hline \multirow[t]{2}{*}{ Net international investment position } & -434.6 & -565.4 & -658.2 & -761.6 & -874.6 & -993.7 & -1120.4 & -1253.2 \\
\hline & \multicolumn{8}{|c|}{ In percent of GDP } \\
\hline Current account & -7.4 & -8.8 & -9.4 & -9.8 & -9.9 & -9.9 & -9.8 & -9.8 \\
\hline Trade balance of goods and services & -5.1 & -6.2 & -6.1 & -6.3 & -6.3 & -6.1 & -5.9 & -5.8 \\
\hline Exports of goods and services & 25.6 & 26.0 & 26.6 & 27.3 & 27.9 & 28.7 & 29.4 & 30.3 \\
\hline Exports of goods & 17.3 & 17.6 & 17.5 & 17.9 & 18.3 & 18.7 & 19.1 & 19.7 \\
\hline Exports of services & 8.3 & 8.4 & 9.1 & 9.4 & 9.7 & 10.0 & 10.2 & 10.6 \\
\hline Imports of goods and services & -30.7 & -32.2 & -32.7 & -33.6 & -34.2 & -34.8 & -35.3 & -36.1 \\
\hline Imports of goods & -24.9 & -25.9 & -25.9 & -26.6 & -27.1 & -27.5 & -27.9 & -28.5 \\
\hline Imports of services & -5.8 & -6.3 & -6.8 & -7.0 & -7.1 & -7.2 & -7.4 & -7.5 \\
\hline Balance of factor income & -1.9 & -2.1 & -2.5 & -2.5 & -2.6 & -2.6 & -2.7 & -2.7 \\
\hline Balance of current transfers & -0.3 & -0.5 & -0.8 & -1.0 & -1.1 & -1.2 & -1.2 & -1.2 \\
\hline Capital account & 0.9 & 0.6 & 0.5 & 0.5 & 0.4 & 0.4 & 0.3 & 0.3 \\
\hline Financial account & 6.6 & 8.5 & 8.9 & 9.3 & 9.5 & 9.5 & 9.5 & 9.5 \\
\hline Net international investment position & -48.0 & -57.9 & -63.0 & -68.4 & -73.9 & -79.1 & -84.2 & -89.5 \\
\hline \multicolumn{9}{|l|}{ Memorandum item: } \\
\hline Trade balance of goods & -7.6 & -8.3 & -8.5 & -8.8 & -8.8 & -8.8 & -8.8 & -8.8 \\
\hline
\end{tabular}

Sources: Bank of Spain; and IMF staff projections. 
Table 6. Spain: Status of Implementation of Main FSAP Recommendations

Adoption timeframe

(since June 2006)

Status

\section{Macro Relevant Recommendations}

Tighten provisioning or capital requirements for nontraditional housing and construction loans

Adopt most conservative approach under Basel II for industrial participations

\section{Financial Sector Supervision}

Ongoing reforms of the Statutes of the Autonomous Communities should clearly maintain prudential and supervisory responsibilities at the State level

Separate insurance supervision from the Ministry of Economy

Delegate the authority to issue norms and sanction violations from the Ministry of Economy and the Council of Ministers to the respective regulatory agencies

Create an institutional mechanism for permanent and continued coordination among the main regulators longer non-renewable terms

\section{Issues Related to Savings Banks}

Monitor the results of the 2002-03 regulations on the governance of savings banks, particularly as regards outside influence on the decisions of savings banks, strengthening them if required

Allow savings banks to merge freely within and across Autonomous Communities if the Bank of Spain approves

Promote use of cuotas participativas to raise high-quality capital and to introduce market discipline

Reduce over time public sector representation ceiling on savings bank boards
Short term or within 12 months

\section{Pending}

Short term

Medium term

Pending

Contemplated in the current draft of Basel II legislation to be adopted by the end of 2007

Despite some ambiguities, Statute revisions basically maintain status quo whereby Bank of Spain retains full responsibility for prudential and supervisory tasks

A proposal to transfer solvency regulation to the Bank of Spain and consumer protection issues to the CNMV is currently stalled

Establishment of the Financial Stability Committee

Pending

Medium term or 1 to 3 years

Ongoing public debate

No requests for mergers have been formulated in

Medium term the last year

Continued active encouragement of issuance, but Medium term none to date Medium term
Ongoing public debate

\section{CInternational Monetary Fund. Not for Redistribution}




\section{Appendix I. Authorities' Study on Immigration}

Spain's economic growth during 2001-06 has been remarkable-3.3 percent annually compared with the euro area's 1.5 percent. About 60 percent of this performance stems from labor mobilization, with immigrants (2.1 million) in turn accounting for half of the employment growth. A recent report by the authorities ${ }^{4}$ analyzes the impact of immigration in detail, with the following conclusions:

- Immigrants are mainly from Latin America (45 percent) and Europe (34 percent); and medium- to high-skilled. Immigrants have on average an educational attainment higher than the native population, although the relationship reverts when comparing similar age cohorts. Job overqualification is more common among immigrants than among natives.

- Immigration has raised income per capita, fostered employment of natives, and improved labor market flexibility. According to the authorities, immigration accounted directly for one-fourth of the 1.6 percent annual income per capita growth during 2001-05. Indirectly, it also raised occupation rates among natives - including female participation by providing domestic services. It helped labor market flexibility through higher geographical and sectoral mobility, and it possibly slowed real wage growth (controlling for human capital, immigrants earn 7

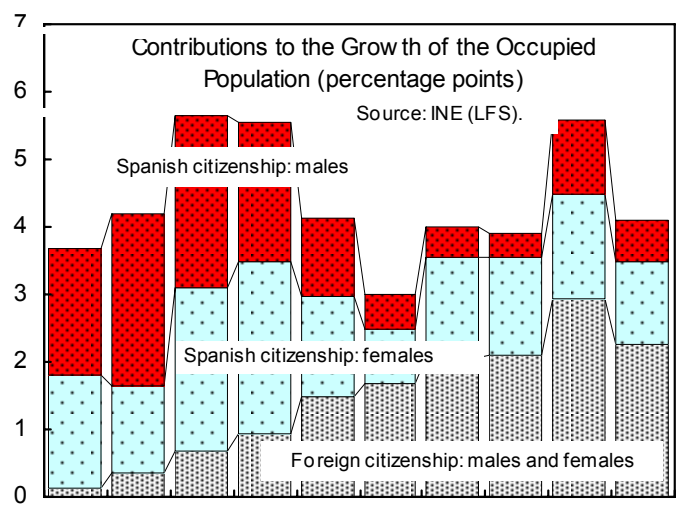

1997199819992000200120022003200420052006 percent less than the native population).

- On balance, immigration has improved the fiscal accounts. In 2005, immigrants accounted for 6.6 percent of fiscal revenues and received 5.4 percent of fiscal expenses - with a net effect equivalent to half of the fiscal surplus. Immigrants' net fiscal contribution is projected to peak in 2012 and become negative by 2030 owing to retirement.

- The authorities estimate that immigration has had an appreciable negative effect on Spain's current account. This is attributed to three main factors: (i) immigrants' remittances; (ii) higher borrowing to purchase durables and housing; and (iii) induced investment through a higher marginal return on capital.

- There is room for further demographic growth. Despite recent inflows, Spain's 2005 immigrants-to-population ratio (12 percent) ranked about the middle of OECD countries. The population density is 68 percent of the euro area, and large regions still have low immigration levels.

\footnotetext{
${ }^{4}$ Specifically, by the Economic Office of the President; see http://www.la-moncloa.es/default.htm.
} 


\section{Appendix II. Spain: Fund Relations}

(As of February 28, 2007)

Mission: Madrid, March 19-26, 2007. The concluding statement of the mission is available at http://www.imf.org/external/np/ms/2007/032607b.htm.

Staff team: Mr. Leipold (head), Mr. Escolano, Ms. Gutierrez, and Mr. Bennett (all EUR). Mr. Guzmán (Alternate to Executive Director) and Ms. Mira (OED) also participated in most meetings.

Country interlocutors: The mission met with the Second Vice-President of the Government and Minister of Economy and Finance Mr. Pedro Solbes Mira, the Bank of Spain Governor Mr. Miguel Fernández Ordóñez, and other senior officials; Congress's Economy and Finance Committee; employers and labor unions; representatives of the opposition; and representatives of the private sector.

Data: Spain subscribes to the Fund's Special Data Dissemination Standard, and economic data are adequate for surveillance.

I. Membership Status: Spain became a member of the Fund on September 15, 1958. On July 15, 1986, Spain accepted the obligations of Article VIII Sections 2, 3, and 4 of the Articles of Agreement.

II. General Resources Account:

SDR Million

$3,048.90$

$2,819.84$

229.04

Reserve position

III. SDR Department:

Net cumulative allocation

Holdings
SDR Million

298.81

219.55
Percent Quota

100.00

92.49

7.51

\section{Percent Allocation}

100.00

73.48

IV. Outstanding Purchases and Loans: None

V. Latest Financial Arrangements: None 
VI. Projected Payments to Fund:

\begin{tabular}{lccccc}
\multicolumn{7}{c}{ Forthcoming } \\
\hline & 2007 & 2008 & 2009 & 2010 & 2011 \\
\cline { 2 - 6 } Principal & & & & & \\
Charges/Interest & 2.52 & 3.39 & 3.39 & 3.39 & 3.39 \\
$\quad$ Total & 2.52 & 3.39 & 3.39 & 3.39 & 3.39 \\
\hline
\end{tabular}

VII. Exchange Rate Arrangement: Spain entered the final stage of European Economic and Monetary Union on January 1, 1999, at a rate of 166.386 Spanish pesetas per euro.

Spain maintains an exchange system free of restrictions on the making of payments and transfers for current international transactions, except for the exchange restrictions imposed by Spain solely for the preservation of national or international security that have been notified to the Fund pursuant to Executive Board Decision No. 144-(52/51).

VIII. Article IV Consultations: The last Article IV consultation was concluded on June 12, 2006. Spain is on the standard 12-month consultation cycle. 


\section{Statement by the IMF Staff Representative}

May 16, 2007

1. This statement provides information that has become available since the issuance of the 2007 Article IV Staff Report. The thrust of the staff appraisal remains unaltered.

2. The economy continues to grow strongly. Bank of Spain estimates place GDP growth at 4 percent in the first quarter of 2007 (year-on-year), the same pace as that observed in the last quarter of 2006. The pattern of growth is also estimated to have remained stable, without significant changes in the dominant contribution to growth of domestic demand and in the drag exerted by the external sector. Private consumption and equipment investment remained dynamic, while construction activity decelerated in line with the gradual cooling of the housing market. Through April, inflation remained around $2 \frac{1}{2}$ percent, with the differential vis-à-vis the euro area hovering in the $0.5-0.7$ percentage point range.

\section{Recent stock market turbulence reflects a correction of the overvalued} construction sector, while highlighting the risks to a soft landing. At end-April, construction company stocks declined sharply, with some spillover to banks (heavily exposed to the real estate sector). The cumulative decline of the IBEX 35 index from its peak has however been relatively contained, bringing the index, which has experienced considerably larger gains than in the euro area, to end2006 levels — still viewed as richly valued by several market analysts. Volatility and some downward sentiment remain, with observers pointing to the risk of a spillover to construction activity—a risk officially viewed as contained.

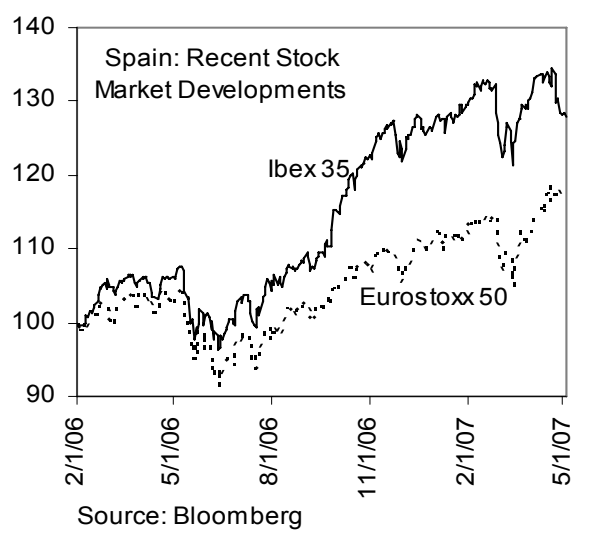

\section{Strong revenues continue to boost the fiscal accounts; a small surplus target has} been set for regional governments in 2008. Exceptionally strong revenue collection raised the central government surplus in the first quarter of 2007 to almost 0.7 percent of (projected) annual GDP, compared to 0.5 percent of annual GDP in the same period of 2006. The authorities cautioned however that this outcome does not yet reflect the effects of the 2006 tax reform, which stand to dampen the likely full-year revenue outturn. In April, the government and the regions agreed to a surplus target for regional budgets of $1 / 4$ percent of GDP in 2008 -a relatively modest objective in the current cyclical circumstances.

\section{Controversy surrounding the takeover process of a large electricity company has} renewed attention on the independence of the regulatory authorities. Divergences of view over the handling of the protracted takeover bid led to the resignation of the head of the securities commission. His replacement failed to garner the support of the opposition and the issue remains the subject of parliamentary enquiries and debate. 


\section{INTERNATIONAL MONETARY FUND}

EXTERNAL

Public Information Notice

RELATIONS

DEPARTMENT

Public Information Notice (PIN) No. 07/54

FOR IMMEDIATE RELEASE

May 18, 2007

International Monetary Fund

$70019^{\text {th }}$ Street, NW

Washington, D. C. 20431 USA

\section{IMF Executive Board Concludes 2007 Article IV Consultation with Spain}

On May 16, 2007, the Executive Board of the International Monetary Fund (IMF) concluded the Article IV consultation with Spain. ${ }^{1}$

\section{Background}

The prolonged phase of economic expansion continued in 2006, with growth accelerating during the year to reach an average 3.9 percent. Domestic demand remained the engine of growth, but demand composition showed some signs of rebalancing. Private consumption and housing investment growth moderated, affected by rising interest rates and stretched household balance sheets. In turn, nonhousing investment and export growth quickened, supported respectively by rising corporate profitability and firming external demand. On the supply side, industrial output and productivity picked up. Job creation continued at a fast pace, with further declines in unemployment and increases in occupation rates. Buoyant fiscal revenues raised the general government surplus to an unprecedented 1.8 percent of GDP_despite steadily rising primary expenditure-and public debt declined below 40 percent of GDP.

The current account deficit widened to 8.8 percent of GDP and net external liabilities rose to 58 percent of GDP. The latter's domestic counterpart was rising private sector indebtedness, which reached 185 percent of GDP. A modest deceleration in household lending was offset by

\footnotetext{
${ }^{1}$ Under Article IV of the IMF's Articles of Agreement, the IMF holds bilateral discussions with members, usually every year. A staff team visits the country, collects economic and financial information, and discusses with officials the country's economic developments and policies. On return to headquarters, the staff prepares a report, which forms the basis for discussion by the Executive Board. At the conclusion of the discussion, the Managing Director, as Chairman of the Board, summarizes the views of Executive Directors, and this summary is transmitted to the country's authorities.
} 
strong corporate borrowing reflecting substantial investment and M\&A activity. Average annual inflation increased in 2006, but inflation and the inflation differential with the euro-area average narrowed by end-2007 as oil prices declined and pressures from household spending eased somewhat. The favorable economic environment underpinned strong financial sector

profitability. Loan losses, although rising, remained at low levels and well provisioned. Exposure to the real estate sector, however, continued to increase.

\section{Executive Board Assessment}

Directors commended the stability-oriented macroeconomic policies and structural reforms that have underpinned Spain's prolonged economic expansion. They welcomed the continued strong output and employment growth observed in 2006 and so far in 2007, as well as the incipient rebalancing of the sources of growth as reflected in a slowing of housing investment and some strengthening of exports. Directors noted these developments were in line with the central scenario of a smooth deceleration of growth over the medium term. Directors also welcomed the positive contribution of large immigration flows to Spain's growth performance.

Directors, nevertheless, cautioned that the sustained increase in private sector indebtedness, reflected in the widening current account deficit, poses risks going forward. In particular, they noted that a sharper-than-expected balance-sheet consolidation, a possible correction in high real estate valuations, and the need to regain competitiveness within EMU may-given persistent economic rigidities-entail a possibly protracted period of slow growth. To forestall such a scenario, Directors stressed the need to safeguard budgetary stability while tempering demand; to expand supply and improve competitiveness by increasing productivity and reducing inflation relative to the euro area; and to preserve financial sector stability.

Directors welcomed the unprecedented fiscal surplus of 1.8 percent of GDP in 2006 and the reduction of government debt to less than 40 percent of GDP. They noted however that this result was due to revenue buoyancy and that primary spending has been rising steadily. Directors thus called for a more resolute expenditure-based countercyclical fiscal stance in the current favorable environment, in keeping with the new Budget Stability Law. To this end, many Directors advised that the 2008 budget aim to keep central government primary expenditure constant as a share of GDP. While Directors saw merit in the authorities' strategy to increase spending on infrastructure, research and development, and education, some suggested that a thorough review of the efficiency of such spending be undertaken.

Directors stressed that regional governments, which account for a large share of expenditure, should contribute to fiscal restraint by aiming for an appropriately ambitious surplus. Successful implementation of the Budget Stability Law also requires strengthening fiscal accountability by improving transparency of the public accounts, in particular through more timely reporting of fiscal data at the territorial level. 
Directors underscored the need for further steps to secure longer-term fiscal sustainability, particularly in light of the potential budgetary impact of the ageing population. While welcoming the continued accumulation of social security surpluses in the Reserve Fund and the contribution of the recent pension reform, Directors encouraged early action in the next legislature to place the pension and health care systems on a sustainable long-term path.

Directors encouraged determined implementation of the authorities' National Reform Program, which addresses some of the key factors constraining productivity. They called, in particular, for stepped-up implementation of competition-enhancing efforts, underpinned by a strong political commitment to promoting contestable markets. Specifically, Directors supported early passage of the new Competition Law, proactive exercise of the competition authority's new powers, and a strengthening of the independence of sectoral regulators. Directors also saw implementation of the EU Services Directive as an opportunity to foster deregulation and competition in sheltered sectors. Several Directors also noted the need for more ambitious labor market reforms.

Directors welcomed the vibrancy, soundness, and stability of the financial sector, and encouraged continued Bank of Spain vigilance in the face of strong credit growth and exposure to the real estate sector. Directors looked forward to passage of pending legislation to implement the Markets in Financial Instruments Directive and Basel II.

Public Information Notices (PINs) form part of the IMF's efforts to promote transparency of the IMF's views and analysis of economic developments and policies. With the consent of the country (or countries) concerned, PINs are issued after Executive Board discussions of Article IV consultations with member countries, of its surveillance of developments at the regional level, of post-program monitoring, and of ex post assessments of member countries with longer-term program engagements. PINs are also issued after Executive Board discussions of general policy matters, unless otherwise decided by the Executive Board in a particular case. 
Spain: Selected Economic Indicators, 2002-06

\begin{tabular}{|c|c|c|c|c|c|}
\hline & 2002 & 2003 & 2004 & 2005 & 2006 \\
\hline \multicolumn{6}{|l|}{ Real economy (change in percent) } \\
\hline Real GDP & 2.7 & 3.0 & 3.2 & 3.5 & 3.9 \\
\hline Domestic demand & 3.2 & 3.8 & 4.8 & 5.0 & 4.6 \\
\hline HICP (average) & 3.6 & 3.1 & 3.1 & 3.4 & 3.6 \\
\hline Unemployment rate (in percent) & 11.5 & 11.5 & 11.0 & 9.2 & 8.5 \\
\hline \multicolumn{6}{|c|}{$\begin{array}{l}\text { Public finance (general government; in percent of } \\
\text { GDP) }\end{array}$} \\
\hline Overall balance & -0.3 & 0.0 & 0.5 & 1.1 & 1.8 \\
\hline Primary balance & 2.4 & 2.3 & 2.6 & 2.9 & 3.5 \\
\hline \multicolumn{6}{|l|}{ Interest rates } \\
\hline Money market rate & 3.3 & 2.3 & 2.0 & 2.1 & 2.8 \\
\hline Government bond yield & 5.0 & 4.1 & 4.1 & 3.4 & 3.8 \\
\hline \multicolumn{6}{|l|}{ Balance of payments (in percent of GDP) } \\
\hline Trade balance & -5.0 & -5.1 & -6.4 & -7.6 & -8.3 \\
\hline Current account & -3.3 & -3.5 & -5.3 & -7.4 & -8.8 \\
\hline \multicolumn{6}{|l|}{ Fund Position (as of February 28, 2007) } \\
\hline Holdings of currency (in percent of quota) & & & & & 92.5 \\
\hline Holdings of SDRs (in percent of allocation) & & & & & 73.5 \\
\hline Quota (in millions of SDR) & & & & & $3,048.9$ \\
\hline \multicolumn{6}{|l|}{ Exchange rate } \\
\hline Exchange rate regime & \multirow{2}{*}{\multicolumn{5}{|c|}{$\begin{array}{l}\text { Euro Area Member } \\
\text { US\$ } 1.3428 \text { per euro }\end{array}$}} \\
\hline Present rate (April 05, 2007) & & & & & \\
\hline Nominal effective rate $(2000=100)$ & 102.9 & 106.7 & 107.8 & 105.9 & 107.0 \\
\hline Real effective rate $(2000=100)$ & 106.4 & 111.1 & 113.3 & 113.3 & 114.8 \\
\hline
\end{tabular}

Sources: INE; Bank of Spain; IFS; and IMF staff estimates. 